Chapter 6

\title{
Extreme Temperature Responses, Oxidative Stress and Antioxidant Defense in Plants
}

\author{
Mirza Hasanuzzaman, Kamrun Nahar and \\ Masayuki Fujita \\ Additional information is available at the end of the chapter \\ http://dx.doi.org/10.5772/54833
}

\section{Introduction}

Temperature stress is becoming the major concern for plant scientists worldwide due to the changing climate. The difficulty of climate change is further added considering its precisely projecting potential agricultural impacts $[1,2]$. Temperature stress has devastating effects on plant growth and metabolism, as these processes have optimum temperature limits in every plant species. Global climate change is making high temperature (HT) a critical factor for plant growth and productivity; HT is now considered to be one of the major abiotic stresses for restricting crop production [3]. The US Environmental Protection Agency (EPA) indicates that global temperatures have risen during the last 30 years [4], and it was mentioned that the decade from 2000 to 2009 was the warmest ever recorded.

High temperature stress is defined as the rise in temperature beyond a critical threshold for a period of time sufficient to cause irreversible damage to plant growth and development [5]. The growth and development of plants involves a countless number of biochemical reactions, all of which are sensitive to some degree to temperature [6]. Consequently, plant responses to HT vary with the extent of the temperature increase, its duration, and the plant type. Worldwide, extensive agricultural losses are attributed to heat, often in combination with drought or other stresses [7].

Low temperature (LT) or cold stress is another major environmental factor that often affects plant growth and crop productivity and leads to substantial crop losses [8,9]. Chilling stress results from temperatures cool enough to produce injury without forming ice crystals in plant tissues, whereas freezing stress results in ice formation within plant tissues. Plants differ in their tolerance to chilling $\left(0-15^{\circ} \mathrm{C}\right)$ and freezing $\left(<0^{\circ} \mathrm{C}\right)$ temperatures. Both chilling and freezing 
stresses are together termed low temperature or cold stress: the damage due to cold stress can range from chilling injury and freezing injury to suffocation and heaving. In general, plants from temperate climatic regions are considered to be chilling tolerant to variable degrees, and their freezing tolerance can be increased by exposing to cold, but non-freezing, temperatures; this process is known as cold acclimation. However, generally the plants of tropical and subtropical origins are sensitive to chilling stress and lack this mechanism of cold acclimation [9]. Low temperature may affect several aspects of crop growth; viz., survival, cell division, photosynthesis, water transport, growth, and finally crop yield.

The cellular changes induced by either HT or LT include responses those lead to the excess accumulation of toxic compounds, especially reactive oxygen species (ROS). The end result of ROS accumulation is oxidative stress [10-12]. In response to HT, the reaction catalyzed by ribulose-1,5-bisphosphate carboxylase oxygenase (RuBisCO) can lead to the production of $\mathrm{H}_{2} \mathrm{O}_{2}$ as a consequence of increases in its oxygenase reactions [13]. On the other hand, LT conditions can create an imbalance between light absorption and light use by inhibiting the activity of the Calvin-Benson cycle. Enhanced photosynthetic electron flux to $\mathrm{O}_{2}$ and overreduction of the respiratory electron transport chain (ETC) can also result in ROS accumulation during chilling which causes oxidative stress [14]. Plants have evolved a variety of responses to extreme temperatures those minimize damages and ensure the maintenance of cellular homeostasis [15]. A considerable amount of works have explored that there is a direct link between ROS scavenging and plant stress tolerance under temperature extremes [12]. Thus, the improvement of temperature stress tolerance is often related to enhanced activities of enzymes involved in antioxidant systems of plants. Plants exposed to extreme temperatures use several non-enzymatic and enzymatic antioxidants to cope with the harmful effects of oxidative stress; higher activities of antioxidant defense enzymes are correlated with higher stress tolerance. Different plant studies have revealed that enhancing antioxidant defense confers stress tolerance to either HT or LT stress [16-19].

In this chapter, we review the recent research findings those revealed variable responses of plants to extreme temperatures. We also focus on the oxidative stress and antioxidant defenses that are invoked by plants for survival under temperature stress conditions.

\section{Plant responses to high temperature}

\subsection{Seed germination and emergence}

Seed germination and seedling vigor are important traits for obtaining a good plant stand and subsequent high yields of a crop. Seed germination is highly dependent on temperature as temperature is one of the basic requisites of this process. However, the range of temperature in which seeds perform better germination depends largely on crop species (Table 1). Soil temperature is one of the major environmental factors that influences not only the proportion of germinated seeds, but also the rate of emergence and the subsequent establishment, even under optimum soil and irrigation conditions [20]. 


\begin{tabular}{|c|c|c|c|}
\hline \multirow{2}{*}{ Crop species } & \multicolumn{3}{|c|}{ Temperature $\left({ }^{\circ} \mathrm{C}\right)$} \\
\hline & Minimum & Maximum & Optimum \\
\hline Rice (Oryza sativa) & 10 & 45 & $20-35$ \\
\hline Wheat (Triticum aestivum) & 20 & 40 & $25-30$ \\
\hline Maize (Zea mays) & 10 & 40 & $25-30$ \\
\hline Soybean (Glycine max) & 10 & 35 & $25-30$ \\
\hline Tomato (Solanum lycopersicum) & 11 & 30 & $15-27$ \\
\hline Cucumber (Cucumis sativus) & 18 & 30 & $25-30$ \\
\hline Egg plant (Solanum melongena) & 15 & 33 & $20-25$ \\
\hline Peeper (Capsicum spp.) & 15 & 35 & $20-30$ \\
\hline Pumpkin (Cucurbita moschata) & 15 & 40 & $20-25$ \\
\hline Water melon (Cucumis melo) & 15 & 35 & $25-30$ \\
\hline Lettuce (Lactuca sativa) & 4 & 25 & $15-20$ \\
\hline Carrot (Daucus carota) & 11 & 30 & $15-25$ \\
\hline Cabbage (Brassica oleracea var. capitata) & 8 & 35 & $15-30$ \\
\hline Spinach (Spinacia oleracea) & 5 & 30 & $15-20$ \\
\hline
\end{tabular}

Table 1. Ranges of temperatures for seed germination of different crops [21, 22]

Roberts [23] documented three distinct physiological processes during seed germination which are affected by temperature: 'first, temperature, together with moisture content, determines the rate of deterioration in all seeds; second, temperature affects the rate of dormancy loss in dry seeds and the pattern of dormancy change in moist seeds; and, third, in non-dormant seeds, temperature determines the rate of germination' (for review see [24]).

The effect of HT on germination was investigated in various crops and serious impacts of HT on seed germination were observed. Increasing temperature between base and optimum temperatures increased the rate of germination and total percentage germination, but temperatures above optimum decrease the germination percentage [Prasad et al. 2006]. Essemine et al. [25] observed that very $\mathrm{HT}\left(45^{\circ} \mathrm{C}\right)$ did not allow adequate rate of germination due to cell death and embryo damage in T. aestivum during the early stage of development (first 6- $\mathrm{d}$ of growth), indicating that HT is not favorable to wheat growth and did not permit establishment of new seedlings. In some cases, plants grown under HT also produce low quality seeds which have poor germination and vigor. Recently, Kumar et al. [26] observed that growth of roots and shoots in hydroponically grown Phaseolus aureus seedlings was not inhibited at $35 / 25^{\circ} \mathrm{C}$ (day/night temperature), but at $40 / 30$ and $45 / 35^{\circ} \mathrm{C}, 18$ and $34 \%$ reduction of shoot growth was observed. The root growth at these temperatures was inhibited by 13 and 23\%, respectively. When Vigna mungo seeds were exposed to 10,20 and $30 \mathrm{~min}$ of heat $\left(50^{\circ} \mathrm{C}\right)$, Piramila et al. [27] observed that seed germination as well as vigor index was significantly reduced by high 
temperature. Pant et al. [28] observed that when seeds of Cassia tora were incubated under normal room temperature they exhibited $92 \%$ germination but when exposed to 40,50 and $60^{\circ} \mathrm{C}$ continuously for $10 \mathrm{~d}$ the germination percentage decreased to 85,63 and $32 \%$, respectively. Several earlier investigators have suggested that HT may be necessary for adequate release of energy for germination and growth [29-31], but it can also reduce plant emergence. Hall [32] stated that the maximum threshold temperatures for germination and emergence are higher for warm-season than for cool-season annuals. For instance, the threshold maximum seed zone temperature for the emergence of Vigna unguiculata is about $37^{\circ} \mathrm{C}$, whereas in Lactuca sativa, it is $25-33^{\circ} \mathrm{C}$.

\subsection{Growth and morphology}

The most observed effect of heat stress on plants is the retardation of growth. As heat stress often occurs simultaneously with drought stress, the combination of drought and heat stress induce more detrimental effect on growth and productivity of crops than when each stress was applied individually [24]. In higher plants, heat stress significantly alters cell division and cell elongation rates which affect the leaf size and weight. However, it was reported that heat stress resulted in significant increases in leaf numbers, particularly when reproductive development was arrested without any decrease in leaf photosynthetic rates [20,24]. Exposure of plants to severe heat stress decreased the stem growth resulting in decreased plant height [20]. Rahman [33] reported that plant height of wheat plant ranges from $66.4-97.3 \mathrm{~cm}$ and $55.7-82.3 \mathrm{~cm}$ in normal and heat stress condition, respectively. While studying with $T$. aestivum, Ahamed et al. [34] observed that sowing time mediated heat stress negatively influenced the plant height and number of tillers of 4 different genotypes. In a recent study, Al-Busaidi et al. [35] observed that high atmospheric temperature cause significant water loss which negatively influenced the growth and biomass production in biofuel plant, Jatropha curcas. Parallel to shoot growth heat stress often decreases root growth, number of roots and root diameter [36].

High temperature decreased shoot dry weight, relative growth rate (RGR) and net assimilation rate (NAR) in maize, millet and sugarcane [5, 37]. In their review, Wahid [5] mentioned that HT can cause considerable pre- and post-harvest damages, including scorching of leaves and twigs, sunburns on leaves, branches and stems, leaf senescence and abscission, shoot and root growth inhibition, fruit discoloration and damage. High temperature also alters the internal morphology (anatomy) of plants and these changes are generally similar to those under drought stress. Under HT stress, there is a general tendency towards reduced cell size, closure of stomata and curtailed water loss, increased stomatal density and trichomatous densities, and larger xylem vessels in both roots and shoots [5]. Several lines of study indicate that exposure of plants to HT resultes in the disintegration of ultrastructural characteristics, mainly attributed to a lower stomatal density, larger stomatal chamber with a larger stomatal opening area, thinner leaves, loose arrangement of mesophyll cells, a partially developed vascular bundle and unstable organelle structure. Zhang et al. [38] examined the microscopic and ultrastructural characteristics of mesophyll cells in flag leaves of both HT sensitive and tolerant rice genotypes grown under heat stress $\left(37 / 30^{\circ} \mathrm{C}\right)$ and reported that the membrane permea- 
bility increased in both sensitive and tolerant plants under HT stress. However, under the HT stress, the tolerant plants showed tightly arranged mesophyll cells in flag leaves, fully developed vascular bundles and some closed stomata, whereas the sensitive plants suffered from injury because of the poor structures of these organs [38]. Recently, Johkan et al. [22] observed that the number of tillers in wheat plants decreased in response to HT, especially high night-time temperatures, however shoot elongation was promoted.

\subsection{Physiological effects}

Physiological processes of plants are largely affected by the alteration of surrounded environmental temperature. The ability of plants to cope with extreme temperature is a complex process and is determined by environmental factors and also by the genetic capability of the plant. In general, stability of life processes in most plants is comparatively wide which ranges from several degrees above zero to around $35^{\circ} \mathrm{C}[6]$. The increase of temperature up to a certain level increases plant growth, photosynthesis, respiration and enzyme activity and after that these parameters tend to decline (Fig. 1). Respiration rapidly increases with temperature and drops drastically after an extreme tolerable temperature. Photosynthesis is a comparatively less sensitive than respiration process but its declining pattern is as like as respiration. The average rate of enzymatic reactions increases twofold with every $10^{\circ} \mathrm{C}$ increase in temperature within the range. The optimal temperature for structural integrity and activity of most enzymes are within the range of $30-45^{\circ} \mathrm{C}$; and enzymes are irreversibly denatured and inactivated at temperatures higher than $60^{\circ} \mathrm{C}$ with the exception of thermophilous organisms. Thus each life process has its own referred critical or lethal temperature after that it can not proceeded and causes permanent damage to cell structures and ultimately the cell, plant death as well [6].

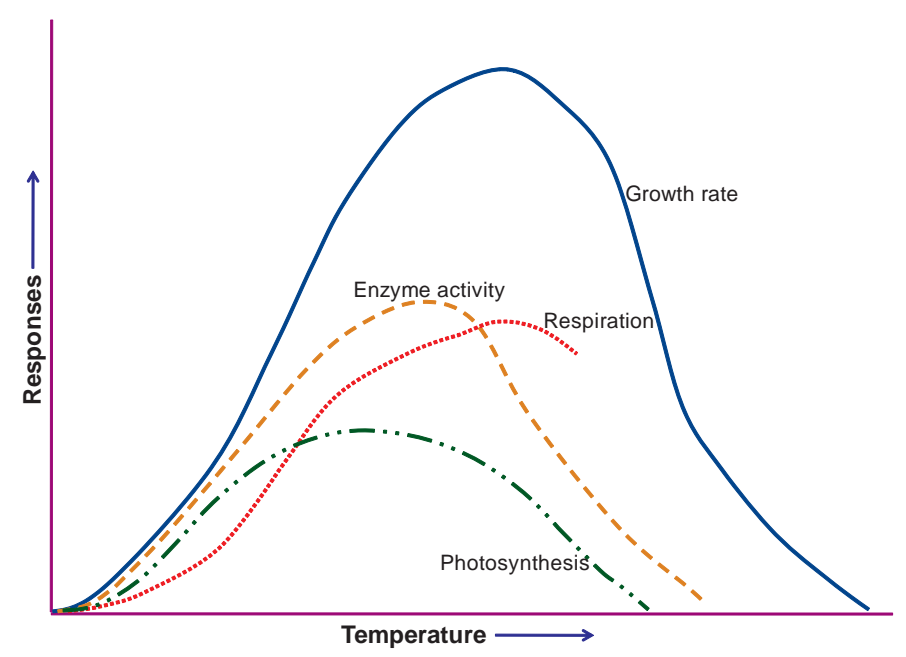

Figure 1. Schematic illustration of the effect of temperature on major physiological processes of plants [6, 39] 


\subsection{Photosynthesis}

Temperature plays one of the most important roles in the rate and ability of a plant to photosynthesize effectively. In general, there is a positive correlation between change in temperature and photosynthesis. But when temperatures exceed the normal growing range $\left(15^{\circ} \mathrm{C}\right.$ to $\left.45^{\circ} \mathrm{C}\right)$ of plants heat injury takes place and HT hurts the enzymes responsible for photosynthesis. Even in the absence of heat stress injury, photosynthesis would be expected to decline as temperature increases because photorespiration increases with temperature faster than does photosynthesis [40].

In tobacco leaves $\mathrm{HT}$ stress $\left(43^{\circ} \mathrm{C}\right.$ for $\left.2 \mathrm{~h}\right)$ decreased the rate of photosynthesis by $38 \%$ compared with that of the rate of photosynthesis at optimal temperature $\left(25^{\circ} \mathrm{C}\right)$. After $1 \mathrm{~d}$ recovery, it reached only about $75 \%$ of its control. Under HT condition, the stomatal conductance $\left(g_{s}\right)$ also decreased significantly [41]. Prasad et al. [42] reported that high night temperature $\left(31.9^{\circ} \mathrm{C} / 27.8^{\circ} \mathrm{C}\right)$ decreased chlorophyll $(\mathrm{Chl})$ content and photosynthetic rate by $8 \%$ and $22 \%$, respectively, compared to optimum night temperature. Deactivation of RuBisCO is one of the causes associated with the decline in photosynthesis under HT. Many authors reported that the heat-induced deactivation of RuBisCO is the primary constraint for photosynthesis at moderately HT and showed that Chl fluorescence signals from PSII are not affected by temperatures that cause significant deactivation of RuBisCO [43]. While studying with oak (Quercus pubescens L.) leaves, Haldimann and Feller [43] concluded that regardless of whether temperature was increased rapidly or gradually, rate of photosynthesis decreased with increasing leaf temperature and it was reduced more than $90 \%$ at $45^{\circ} \mathrm{C}$ as compared to $25^{\circ} \mathrm{C}$. Stomatal conductance is also an important factor that modulate photosynthesis rate in plants. Eamus et al. [44] have shown from the stomatal conductance response of Eucalyptus haemastoma leaves to temperature declined with leaf temperatures above about $30-32^{\circ} \mathrm{C}$, with a considerable reduction at $40^{\circ} \mathrm{C}$. In Semillon leaves, Greer and Weston [45] observed that 4-d heat exposure at $40^{\circ} \mathrm{C}$ caused a sustained reduction in photosynthesis that was $95 \%$ attributed to reduced $g_{s}$ which suggest that stomata of this plant was highly susceptible to heat. Recently, Greer and Weedon [46] observed that average rates of photosynthesis of Vitis vinifera leaves decreased by $60 \%$ with increasing temperature from $25^{\circ} \mathrm{C}$ to $45^{\circ} \mathrm{C}$. This reduction in photosynthesis was attributed to $15-30 \%$ stomatal closure.

It was noted that an increase in temperature of $10^{\circ} \mathrm{C}$ to $15^{\circ} \mathrm{C}$ above normal growth temperature leads to alteration of photosynthetic pigments and thus limiting photosynthesis. The reasons for decreasing in photosynthetic pigments under HT may be attributed to the inhibition of biosynthesis, changes in ultrastructure of chloroplast, especially the membrane, and photodeterioration [47, 48]. Tewari and Tripathy [47] observed that heat stress significantly reduces Chl content in T. aestivum which was due to inhibition of porphobilinogen deaminase activity and thus reduction in protochlide content in the seedlings upon exposure to short duration of heat stress $\left(42^{\circ} \mathrm{C}\right)$. Heat stress has been reported to reduce $\mathrm{Chl}$ content, $\mathrm{Chl} a / b$ ratio and Chl:Car ratio in various plant and tree species like Festuca arundinacea [49] and Solanum spp. [50], T. aestivum [48]. Recently, Almeselmani et al. [51] investigated the performance of heat tolerant (C306) and heat susceptible (PBW343) wheat genotypes under HT $\left(35 / 25^{\circ} \mathrm{C}\right.$ day/night). They observed that HT significantly reduced leaf $\mathrm{Chl}$ content in both genotypes at any stages of 
growth. Heat stress reduced leaf Chl content by 23 and 48\% in C306 at anthesis and 15 days (d) after anthesis respectively, while in PBW343, 29 and 61\% reduction in Chl content at anthesis and $15 \mathrm{~d}$ after anthesis, respectively, was observed under HT as compared with normal temperature [51]. As a result, HT significantly reduced the leaf photosynthetic rate in both genotypes at all three stages of plant growth compared to their respective control. In another study Chl $a$ in the L. esculentum leave was reduced by $10-32 \%$, Chl $b$ by $10 \%$ and $5 \%$ reduction in the ratio of Chl $a$ and $\mathrm{Chl} b$ observed after 2-d of heat treatment [52]. However, the effect of HT on the photosynthesis of the crop also depends on other climatic parameters. In addition it is not always obvious that HT reduces the rate of photosynthesis. For instance, HT had no effect on the photosynthetic temperature response of potato [53] and pea leaves [54]. Furthermore, growth of maize leaves at HT had no effect on their rates of photosynthesis [55].

\subsection{Water relations}

Plant water status is considered as the most important variable under changing ambient temperatures [56]. Plant water relation is more affected under the combined heat and drought stress, than the condition of heat and sufficient moisture level. High temperatures affect seedlings, first, by increasing evaporative demand and tissue damage. High temperaturesinduced increased transpiration and water transportation is another necessary tool for plant survival under extreme temperatures. Death of a large number of Pinus ponderosa seedlings were observed at $63^{\circ} \mathrm{C}$ but among those a few were survived those maintained basal stem temperatures as much as $15^{\circ} \mathrm{C}$ lower than the surrounding air by keeping higher $g_{s}$, transpiration rate and water transportation. Here, water transport through seedling stems may help to cool plant by the heat transferring mechanism. Heat exchange calculations demonstrated that rapid water flow through seedling stems can absorb sufficient energy to reduce the stem temperature by $30^{\circ} \mathrm{C}$ during peak sunlight hours [57]. Triticum aestivum and Hordeum vulgare were grown in soil that was well watered or not watered in controlled chambers at 15/10, 25/20, $35 / 30$ and $40 / 35^{\circ} \mathrm{C}$ day/night temperatures. After two days soil water content, leaf relative water content, leaf water potential, leaf osmotic potential, leaf turgor potential and osmotic adjustment were nearly constant at all temperatures when soil was well watered but were affected strongly by HT when water was withheld [58]. Morales et al. [59] indicated that HTinduced reduction in leaf water status was caused mainly due to reduction in hydraulic conductance leading to decrease in water absorption or due to reduced $g_{s}$. In Lotus creticus elevated night temperatures caused a greater reduction in leaf water potential in waterstressed as compared to well-watered plants [60]. In sugarcane, leaf water potential and its components were changed upon exposure to heat stress even though the soil water supply and relative humidity conditions were optimal, implying an effect of heat stress on root hydraulic conductance [61].

\subsection{Dry matter partitioning}

Dry matter (DM) partitioning varied widely under different temperatures and crops. Stresses like water deficit and heat slower down the assimilation process and the mineral uptake during the grain filling period. Assimilates those are transferred directly to kernels and remobilization 
of assimilates stored in vegetative plant parts both together contribute to grain yield [62]. Sometimes under HT, it happens that the sink activity lost due to the earlier panicle senescence where the source activity still exists as the leaf senescence does not occurs [63, 64]. In those cases, grain filling was terminated earlier than complete leaf senescence. Kim et al. [64] reported that consistently HT increased the rates of grain filling, fraction of DM partitioning to panicle and leaf senescence while it reduced the durations of them under the temperature regime of 24.4 and $21.9^{\circ} \mathrm{C}$ in temperate variety of $O$. sativa. There is a positive contribution of the delayed leaf senescence to grain filling and yield of crop. There are various reasons for loss of sink activity at HT which may result from a decline of translocation ability or loss of activity of starch synthesis-related enzymes. The sucrose synthase activity of rice grain has been observed to be positively correlated with grain sink strength and starch accumulation $[65,66]$. Another reason for decreased grain filling duration of rice under HT is reduction of cell size on the dorsal side close to the vascular bundles [67]. In a pot experiments with 4 Arachis hypogaea genotypes varying in heat tolerance were grown at either $28 / 22$ or $38 / 22^{\circ} \mathrm{C}$ from 21 to $90 \mathrm{~d}$ after planting (DAP). High temperature reduced total dry weight by 20 to $35 \%$, seed harvest index by 0 to $65 \%$, and seed dry weight by 23 to $78 \%$ [68]. There are several reports regarding HT induced declines in shoot DM, relative growth rate and net assimilation rate in Z. mays, Pennisetum glaucum and Saccarum officinarum [37, 69]. In the medicinal plant Panax quinquefolius L., partitioning of DM to roots in the cool greenhouse and in the field was $73 \%$, whereas it was $62.5 \%$ in the heated greenhouses [70].

\subsection{Reproductive development}

It is notable that reproductive development of plants is more sensitive to HT because plant fertility is considerably reduced as temperatures increase [71]. For heat-sensitive plants such as tomato, no fruit set occurs at day/night temperatures of $35 / 23^{\circ} \mathrm{C}$ [72]. Studies on common bean [73], and peach [74] showed that elevated temperatures during flower development can markedly reduce the fruit set. The decrease in the fruit set has generally been attributed to low pollen viability and germinability at HT in crop species such as tomato [75] and groundnut [76]. Porch and Jahn [77] reported that Phaseolus vulgaris exposed to pre-anthesis heat stress resulted in pollen and anther development abnormalities. In soybean, pollen viability was lower at day/night temperature conditions of $37 / 27^{\circ} \mathrm{C}$ than at $27 / 27^{\circ} \mathrm{C}$ which resulted in a lower pod setting [78]. High temperatures inhibit flower differentiation and development, and result in smaller ovaries in pistillate and bisexual flowers [22].

The diurnal variation of temperature is also important for reproductive growth and development. Spikelet fertility of rice is sensitive to night temperature, where the degree of sensitivity depends upon the developmental stage of the spikelet [79]. Later, Peng et al. [80] observed a strong negative linear relationship between the number of fertile spikelets and increase in night temperatures. Ledesma et al. [81] examined the effect of two day/night temperature regimes $\left(30 / 25^{\circ} \mathrm{C}\right.$ and $23 / 18^{\circ} \mathrm{C}$ ) on fruit set and fruit growth in two strawberry cultivars (Nyoho and Toyonoka). It was recorded that high day/night temperature of $30 / 25^{\circ} \mathrm{C}$ reduced the number of inflorescences, flowers, and fruits in both cultivars compared with control $\left(23 / 18^{\circ} \mathrm{C}\right)$. The percentage of fruit set in Nyoho was not significantly different between the two temperature 
treatments, while in Toyonoka it was much lower at $30 / 25^{\circ} \mathrm{C}$ than at $23 / 18^{\circ} \mathrm{C}$. Ripening time was shorter at $30 / 25^{\circ} \mathrm{C}$ than at $23 / 18^{\circ} \mathrm{C}$ in both cultivars.

\subsection{Yield}

As HT negatively affected plant establishment, growth, DM partitioning, reproductive growth and photosynthesis, it ultimately poses serious consequence on crop yield. Several lines of study indicated the reduction of crop yield under HT which greatly varies with the degree and duration of temperature as well as genotypes of the crop (Table 2). Mendham and Salsbury [82] reported that HT can reduce crop yield by affecting both source and sink for assimilates. The decrease in grain length and width of cereals was found to be associated with a reduction in the average endosperm cell area observed under high night temperature [67]. In addition, cereals generally respond to HT through an increase in the rate of kernel growth, which lead to a decrease in the duration of DM accumulation [79]. Kernel dry weight reduced from 79 to $95 \%$ in field conditions in B-73 inbred line of maize under heat stress [83]. Shah and Paulsen [84] demonstrated that photosynthesis and leaf area, shoot, grain biomass and sugar contents of kernels rapidly decreased under HT. High temperature affected the endosperm development in maize and reduced grain yield during endosperm cell division [85]. Prasad et al. [20] observed that an increase in temperature from $32 / 22^{\circ} \mathrm{C}$ to $36 / 26^{\circ} \mathrm{C}$ and $40 / 30^{\circ} \mathrm{C}$ decreased seed yield of sorghum by 10 and $99 \%$, respectively. Djanaguiraman et al. [86] grew sorghum plants both under normal $\left(32 / 22^{\circ} \mathrm{C}\right)$ and $\mathrm{HT}\left(40 / 30^{\circ} \mathrm{C}\right)$ and observed significant differences in yield attributes and yield. After $45 \mathrm{~d}$ of treatment, plant height, leaf dry weight, seed weight and total dry weight decreased by $22,14,53$ and $36 \%$, respectively compared to optimum temperature. Compared to other crops, wheat is the most sensitive to HT as the reproductive growth, especially grain filling is greatly facilitated by LT. Mohammed and Tarpley [87] found almost $90 \%$ less grain in the plants grown in high night temperature $\left(32^{\circ} \mathrm{C}\right)$ compared to normal temperature $\left(27^{\circ} \mathrm{C}\right)$. Plants grown under high night temperature showed $20 \%$ decrease in grain weight compared to plants grown under normal temperature. Johkan et al. [22] reported that HT resulted in more immature grains and decreased yields in T. aestivum because of dark respiration. In a recent study, Prasad et al. [42] observed that spring wheat plants grown under $\mathrm{HT}\left(31 / 18^{\circ} \mathrm{C}\right)$ showed a significant reduction in number of grains spike $\mathrm{s}^{-1}(50 \%)$, total dry weight $(20 \%)$, grain yield $(39 \%)$ and harvest index $(24 \%)$ as compared to optimum temperature $\left(24 / 14^{\circ} \mathrm{C}\right)$.

\begin{tabular}{|c|c|c|c|}
\hline Plant species & Temperature and duration & $\%$ reduction & References \\
\hline \multirow{2}{*}{ Cicer arietinum } & $35 / 16^{\circ} \mathrm{C}$ (day/night), $10 \mathrm{~d}$; during & Pod plant ${ }^{-1}: 53 \%$ & \multirow{2}{*}{ [88] } \\
\hline & flower and pod development & Seed yield: $48 \%$ & \\
\hline \multirow{3}{*}{ Brassica spp. } & \multirow{3}{*}{$\begin{array}{l}35 / 18^{\circ} \mathrm{C}, 10 \mathrm{~d} \text {; during bud formation, } \\
\text { flowering, and pod development }\end{array}$} & Main stem pods: $75 \%$ & \multirow{3}{*}{ [89] } \\
\hline & & Seeds pod ${ }^{-1}: 25 \%$ & \\
\hline & & Seed weight: $22 \%$ & \\
\hline \multirow{2}{*}{ Cicer arietinum } & $35 / 16^{\circ} \mathrm{C}$ (day/night), $10 \mathrm{~d}$ during early & Seed weight: $40 \%$ & \multirow{2}{*}[90]{} \\
\hline & flowering and pod development & Harvest index: $7 \%$ & \\
\hline
\end{tabular}




\begin{tabular}{|c|c|c|c|}
\hline Plant species & Temperature and duration & $\%$ reduction & References \\
\hline Sorghum bicolor & $\begin{array}{l}\text { Increase in temperature from } 32 / 22 \text { to } \\
36 / 26 \text { and } 40 / 30^{\circ} \mathrm{C} \text { (day/night); from } \\
\text { emergence to maturity }\end{array}$ & $\begin{array}{l}\text { Seed yield: } 10 \text { and } 99 \% \text {, } \\
\text { respectively }\end{array}$ & {$[20]$} \\
\hline Triticum aestivum & $\begin{array}{c}5^{\circ} \mathrm{C} \text { higher than optimum; from sowing } \\
\text { to } 60 \mathrm{DAS}, 61-80 \text { DAS and } 81 \text { DAS to } \\
\text { maturity }\end{array}$ & $\begin{array}{c}\text { Grain spike }^{-1}: 18 \% \\
\text { Grain weight: } 19 \% \\
\text { Grain yield plant }{ }^{-1}: 46 \%\end{array}$ & [91] \\
\hline Sorghum bicolor & $40 / 30^{\circ} \mathrm{C}$ (day/night), $63 \mathrm{~d}$ & Seed weight plant ${ }^{-1}: 53 \%$ & [86] \\
\hline Oryza sativa & $35 / 30^{\circ} \mathrm{C}$ (day/night); at heading stage & $\begin{array}{l}\text { Panicle weight: } 7 \% \\
\text { Spikelet weight: } 16 \%\end{array}$ & [92] \\
\hline Oryza sativa & $\begin{array}{l}32^{\circ} \mathrm{C} \text { (10 h night temperature; stating } \\
\text { from } 20 \text { DAE until harvest) }\end{array}$ & Yield per plant ${ }^{-1}: 90 \%$ & [87] \\
\hline Oryza sativa & $34^{\circ} \mathrm{C}, 7 \mathrm{~d}$; during grain filling stage & $\begin{array}{l}\text { Panicles plant }{ }^{-1}: 10 \% \\
\text { Grain yield plant }{ }^{-1}: 39 \% \\
\text { Harvest index: } 30 \%\end{array}$ & [93] \\
\hline Capsicum annum & $\begin{array}{c}29 / 23^{\circ} \mathrm{C} \text { (day/night); from } 7 \text { DAT to } \\
\text { edible maturity }\end{array}$ & $\begin{array}{l}\text { No. of fruits plant }{ }^{-1}: 28 \% \\
\text { Yield plant }{ }^{-1}: 62 \% \\
\text { Fruit length: } 18 \% \\
\text { Fruit diameter: } 20 \%\end{array}$ & [94] \\
\hline Triticum aestivum & $\begin{array}{l}31 / 18^{\circ} \mathrm{C} \text { (day/night); from heading to } \\
\text { harvest maturity }\end{array}$ & $\begin{array}{l}\text { Grain number spike }{ }^{-1}: 50 \% \\
\text { Grain yield plant }{ }^{-1}: 39 \%\end{array}$ & [42] \\
\hline Oryza sativa & $27^{\circ} \mathrm{C}$ during grain filling period & Grain weight: 4\% & [95] \\
\hline
\end{tabular}

Table 2. Reduction in yield components and yield of different crops as affected by high temperature

\section{Plant responses to low temperature}

Cold or LT stress comprises of chilling $\left(<20^{\circ} \mathrm{C}\right)$ and freezing temperatures $\left(<0^{\circ} \mathrm{C}\right)$ those hamper the plant growth and development in many ways. Chilling-sensitive plants exposed to LTs usually show water-stress symptoms due to decreased root hydraulic conductance and leaf water and turgor potentials [96]. Cold stress effects on crop plant have been studied since long time in many economically important crops [97-100] among which some of are chilling sensitive and unable to survive cold temperatures. Low temperature affects the plants in every stage of life starting from germination up to maturity.

\subsection{Germination}

Chilling injury is a serious problem during germination and early seedling growth in many plant species. For instance, optimum temperature range for germination of rice seed lies 
between 20 and $35^{\circ} \mathrm{C}$, and the temperature of $10^{\circ} \mathrm{C}$ is cited as the minimum critical value below which rice does not germinate [101]. There are many reports on positive correlation between germination at LT and root development at an early stage; and between the germination and seedling establishment [102]. Angadi et al. [103] observed that the number of days to $50 \%$ germination in $B$. napus was only $3 \mathrm{~d}$ at $8^{\circ} \mathrm{C}$ which was nearly $13 \mathrm{~d}$ at $2^{\circ} \mathrm{C}$. This LT effect was more pronounced in $\mathrm{B}$. rapa, because at $2^{\circ} \mathrm{C}$, emergence was less than $50 \%$, even after $20 \mathrm{~d}$ of sowing [103]. Buriro et al. [104] reported that the increase in temperature significantly enhanced germination and related traits in wheat cultivars. All the wheat varieties germinated well $(80-97 \%)$ sown at $10-30^{\circ} \mathrm{C}$. The maximum seed germination, vigor index occurred at $20-30^{\circ} \mathrm{C}$ and these temperature regimes were identified as optimum for wheat seed germination. The delay in germination percentage and the reduced germination percentages were observed in Gossypium hirsutum at LT below $20^{\circ} \mathrm{C}$ [105]. In T. aestivum, the germination is drastically hampered at temperature below $8-10^{\circ} \mathrm{C}$ [106].

\subsection{Growth and morphology}

Low temperature stress inhibits various metabolic reactions thus preventing the expression of full genetic potential of plants which is expressed by different phenotypic symptoms [107]. Some of the common LT injury in plants are reduced seedling growth, seedling discoloration, leaf yellowing, leaf whitening, white specks, white bands, withering after transplanting, a reduced rate of tillering, stunting and so on [102]. According to Angadi et al. [103], temperatures below $10^{\circ} \mathrm{C}$ result in slower and reduced growth and premature stem elongation in B. napus, $B$. rapa and Raphanus sativus. It is well reported that plants at their seedling stage are very much sensitive to cold stress. At early stage of plant growth, and various phenotypic symptoms in response to chilling stress are surface lesions, chlorosis, necrosis, desiccation, tissue break down and water soaked appearance of tissues, reduced leaf expansion, wilting [108, 109]. Nahar et al. [99] observed varieties of cold injury symptom is rice including stunted growth, yellowing of leaves, abnormal number of tiller, malformed grain, abnormal colors in grain.

Generally, exposure to cold temperature affects crop growth and development in two ways concurrently. First, developmental events in the shoot apex are affected which directly determine the differentiation of the panicle and hence potential yield and spikelet fertility resulting in fewer grains. Second, photosynthesis is impaired which reduces growth and results in indirect yield loss because there is less carbohydrate available for grain production [110]. The cellular structures and components are also damaged due to the cold which have been studied for a long time. The development process and ontogeny of the organelles may be disrupted by chilling stress [111]. Nahar et al. [98, 99] observed cold stress induced morphological symptoms like stunted plant, bushy plants, early maturity, yellowing of leaves. Modifications of cellular components include swelling of mitochondria, plastids and thylakoid lamellae, vesiculation of thylakoid, accumulation of lipid droplets and eventually the disorganization of the entire plastid [112], reduction in ribosomal numbers, dilation of endoplasmic reticulum, vesiculation of cytoplasmic membranes, condensation of nuclear chromatin, invagination of plasmalemma and vacuolation of membranous vesicles $[111,113]$ were noticed 
during chilling stress. Without these in extreme cases, chilling results in accelerated senescence and eventually plant death [114].

\subsection{Reproductive development}

Reproductive phases of the life cycle of plants are more vulnerable to cold stress [115]. The reproductive phase faced to LT stress is influenced diversely in its different sub-phases. During the development of male gametophyte LT causes disruption of meiosis, tapetal hypertrophy, stunted development of pollen grain, anther protein degradation, pollen sterility, pollen tube deformation. In female gametophyte development its effects are characterized by reduced style and ovary length, disruption of meiosis, reduced stigma receptivity, callose deposition in style, damage to embryo sac components, and arrest of the fertilization process. At flowering LT may cause delayed flowering, bud abscission, sterile or distorted flowers, while at grain filling the source-sink relation is altered, kernel filling rate is reduced and ultimately small sized, unfilled or aborted seeds are produced $[109,116]$. Flower buds of Simmondsia chinensis can be damaged or killed by temperatures of $-2^{\circ}$ to $-5.5^{\circ} \mathrm{C}$ [117]. Farrell et al. [118] observed that cold water significantly reduced panicle emergence in rice. Low temperatures affect not only normal heading but also panicle exsertion and prevent the normal elongation of internodes of rice. Cold stress $\left(11^{\circ} \mathrm{C}\right)$ caused abnormality in panicle initiation process, delayed heading, incomplete panicle emergence, sterile and malformed spikelet and spikelet degeneration symptom in rice genotypes [98, 99b; Fig. 2, 3]. In canola low, but nonfreezing temperatures prior to flowering slow the rate of plant development, delayed flowering, slower the rate of flower opening and reduces the amount of pollen shed and in severe frost the pod abortion is evident in many species [119]. The effect of LT prevailing at the early stages of plant growth is sometimes associated with the premature flowering in Chinese cabbage [120].

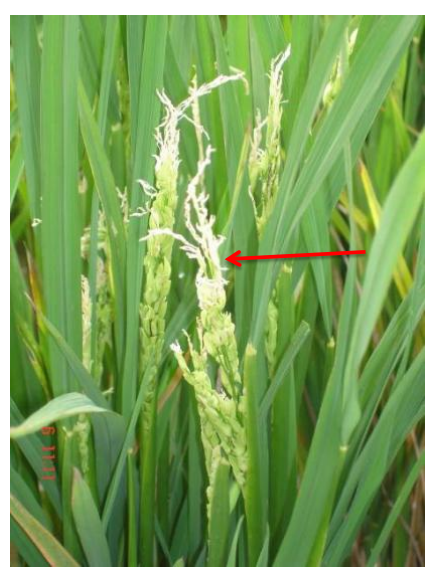

A

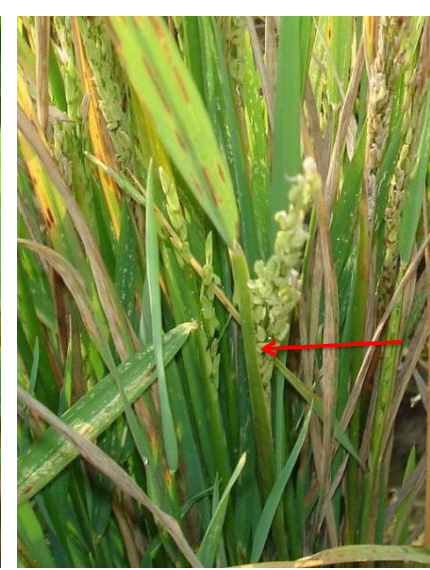

B

Figure 2. Spikelet degeneration (A) and incomplete of panicle exsertion (B) of rice due to cold stress 


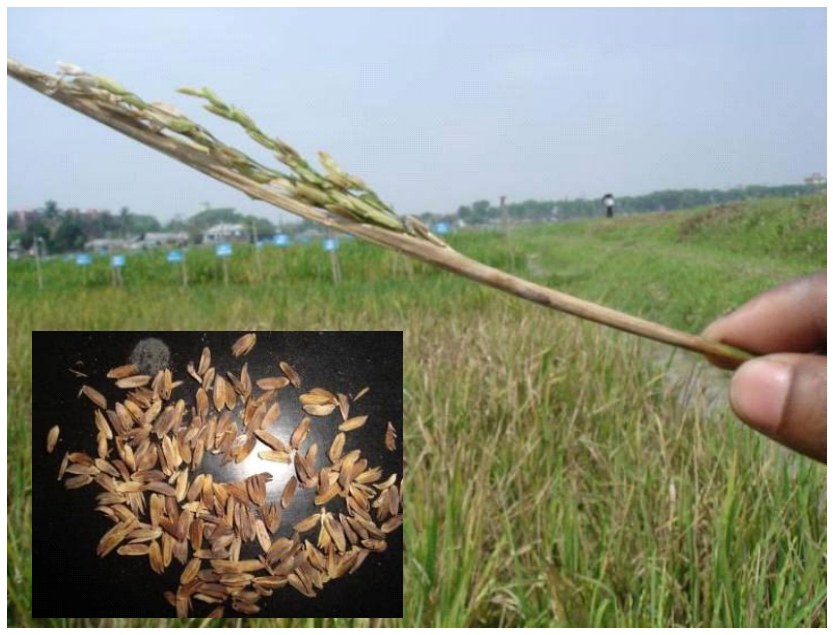

Figure 3. Sterile spikelets of rice due to cold stress

\subsection{Cell membrane damage}

Extreme temperature injuries caused either by cold or by HT first attack on the cell membrane. There are many studies where cellular membranes have been shown as the primary site of freezing injury in plants [121,122]. Cell membrane is damaged in two ways viz. disruption of protein lipid structure, protein denaturation and precipitation of solutes that indulges the membrane permeability. Due to LT stress the fatty acids become unsaturated and the lipid protein ratios of the membrane become altered which ultimately affect the membrane fluidity and structure as well [90]. The flexible liquid-crystalline phase is converted in to a solid gel phase, thereby affecting the cellular function in different ways, viz. increased membrane permeability increases ion leakage, allows the entrance of undesirable anions and cataions into the cell, obstructs the exchange of essential ions, hampers the osmosis and diffusion processes, etc. All the phenomena are responsible for disrupting cellular homeostasis [97]. Conversion of cellular water into ice is a major reason for cell rupture in cold stress. At first the ice formation occurs in apoplast having low solute concentration, this creates a vapor pressure between cytoplasm and apoplast and results in the migration of unfrozen cytoplasmic or cytosol water to the apoplast. This water gives a pressure which is the cause of enlargement of existing ice crystals and the pressure towards the cell wall and cell membrane which leads to cell rupture $[123,124]$.

\subsection{Photosynthesis}

Low temperatures may disturb the key organs of photosynthesis, including chloroplast and thylakoid membranes, causes swelling of plastids and thylakoid lamellae, vesiculation of thylakoid, accumulation of lipid drops and ultimately disorganization of entire plastid [111, 
113]. Low temperature also disrupts the systems including electron transport, carbon cycle metabolism and $g_{s}$. Among the photosynthetic apparatus PSII is the primary target of damage under LT stress. Moreover, LT reduces the activities of stromal and carbon assimilation enzymes like Calvin cycle enzyme, ATP synthase, and restricts RuBisCO regeneration and limits the photophosphorylation [125]. Another impact of LT exposure is the decline of carbon export from leaves which results in the accumulation of soluble carbohydrates [126]. Yordanova and Popova [127] stated that exposure of wheat plants to a LT $\left(3^{\circ} \mathrm{C}\right)$ for $48 \mathrm{~h}$ and $72 \mathrm{~h}$ resulted in decreased levels of $\mathrm{Chl}, \mathrm{CO}_{2}$ assimilation and transpiration rates. Photosynthesis is strongly reduced below $18^{\circ} \mathrm{C}$ [128], while temperatures around $4^{\circ} \mathrm{C}$ dramatically depress photosynthetic performance [129]. The decline of photosynthetic capacity in LT is related to a decrease in the quantum efficiency of PSII and the activities of PS I, the ATP synthase and the stromal enzymes of the carbon reduction cycle [125]. Partelli et al. [130] showed that coffee plant resulted in 30\% reduction in Chl $a, 27 \%$ reduction in Chl b, 29\% reduction of total Chl when the day/night temperature decreasing from $25 / 20^{\circ}$ to $13 / 8^{\circ} \mathrm{C}$. For Car, $86 \%$ reduction of $\alpha$-carotene, $57 \%$ reduction in $\beta$-carotene, $68 \%$ reduction in $\alpha / \beta$-carotene ratio, $32 \%$ reduction in lutein, but $21 \%$ increase in zeaxanthin. In $\mathrm{O}$. sativa, the total $\mathrm{Chl}$ content was reduced by $50 \%$ due to exposure to $\operatorname{LT}\left(15 / 10^{\circ} \mathrm{C}\right)$ for 2 weeks [131]. In a recent study, Reda and Mandoura [48] reported that even at LT stress of $3^{\circ} \mathrm{C}$ the enzyme chlorophylase is still activated and led to a decline in $\mathrm{Chl}$ in T. aestivum plant.

\subsection{Water and nutrients movements and uptakes}

Cell membrane plays major roles in water and nutrient movements within and outwards the cell. Intra- and extracellular water and nutrient movement are inhibited due to LT due to memebrane damage under LT. There can be of two types of abnormalities during LT stress. Cold damages the membrane that makes the membrane permeable to undesired nutrients and ions and causes ion leakage; another is cell membrane and cell wall can be ruptured by the cold which is also responsible for disrupting cellular homeostasis by destroying both intra and extracellular nutrient and water movements $[132,133]$. Severe dehydration may also occur due to freezing of cell constituents, solutes and water [134]. Available literature states that when temperatures drop below $0^{\circ} \mathrm{C}$, the ice formation generally begins in the intracellular spaces because the intracellular fluid has a higher freezing point as compared to the other suborganales of cell $[134,135]$. Low and freezing temperatures also lead to cellular dehydration, reduce water and nutrient uptake and conduction by the roots in some plants, thus causing osmotic stress [107]. Yadav [134] stated that dehydration during cold occurs mainly due to reduction in water uptake by roots and a hindrance to closure of stomata. The success or failure of a seedling in the field is strongly related to the development of its root system under cold stress [136]. In root of cucumber it was found that chilling caused injury to the cortical cells and further long time exposure increased the density of cytoplasm and damage the endoplasmic reticulum [137]. Chilling-sensitive plants exposed to LT usually show water-stress symptoms due to decreased root hydraulic conductance; and decreased leaf water and turgor potentials [96]. Freezing-induced increase in water viscosity is partly accounted for an initial decrease in root hydraulic conductance [138]. During cold stress another phenomenon is common with the imbalanced water movement. The metabolic functions are altered those include production 
of more enzymes, isozymes though they help in maintaining more catalytic activity to cope with the LT stress [139].

\subsection{Yield components and yield}

Reproductive phase products are the key components of economic yield and hence LT stress during the reproductive phase has significant economic and social consequences. All the adverse effects of cold stress ultimately lower the yield of crop. Low temperature-induced yield reduction is a common phenomenon in many crops [98, 99, 140, 141]. Low temperature often causes flower abortion, pollen and ovule infertility, breakdown of fertilization, poor seed filling, decreases in seed setting which ultimately reduce the grain yield [116]. In O. sativa, LTs are responsible for $30-40 \%$ yield reduction in temperate growing areas [142]. It was observed that about 16 and $37 \%$ yield reduction in the rice variety of BRRI dhan 46 and BRRI dhan 31 due to late sowing mediated LT stress [98]. In another report, it was observed that LT stress near about $11^{\circ} \mathrm{C}$ caused yield reduction in maximum genotypes and only 23 genotypes were screened out among the 244 genotypes considering their better yielding ability under LT [99]. The reduction in yield in C. sativus L. was from 15 up to over $18 \%$ due to low soil temperature [143]. In C. melo L., total yields decreased linearly for cold stress (21 and $32 \mathrm{~h}$ ) which accounted for $10 \%$ lower than normal condition [143]. Frost prevailing just after flowering can result in yield reduction and the quality or grade loss. Premature flowering or bolting is occurred due to LT stress which has economic importance for the Chinese cabbage industry because advanced flower stalk development results in an unmarketable head [120]. In B. napus and B. rapa various abnormal structures were observed like reduced diameter and extensive white patches, white reticulation, red-brown pigmentation, folded seed, extensively shriveled seed, etc. those are the causes for reduced market value of this crop[103].

\section{Responses of perennial crops to extreme temperature}

Like annual crops, perennial crops are also sensitive to extreme temperature. Fruits and nut trees are important crop plants which often face extreme temperature stress induced damages. Every fruit tree species has a range of optimum temperatures (Table 3) above or below which the growth and yield markedly reduced. The mean temperatures range for optimum growth of most tropical fruits are about $24-30^{\circ} \mathrm{C}[144,145]$. For instance, mango (Mengifera indica) tree can tolerate $\mathrm{HT}$ up to $48^{\circ} \mathrm{C}$ only for a certain period of time [146], on the contrary it has only partial tolerance to LT. In another study, Schaffer et al. [147] observed that monoembryonic mango cultivars tend to be more LT tolerant than polyembryonic cultivars [147]. However, several studies have shown that LT promote reproductive morphogenesis in mango. Dinesh and Reddy [145] studied the responses of fruit trees to temperature and observed differential responses to temperature in different fruit species. They concluded that lychee and longan require a warm sub-tropical to tropical climate that is cool but also frost-free or with only very slight winter frosts not below $-4^{\circ} \mathrm{C}$, and with high summer heat, rainfall, and humidity. In longan, stressful temperatures of $<15^{\circ} \mathrm{C}$ at the young fruit stage reduce fruit growth potential and final size as reported by Young et al. [148]. Stressful LT also induces excessive fruit drop 
and severe fruit cracking [148]. In a previous study, Tindal [149] reported that rambutan is adapted to warm tropical climates of approximately $22-30^{\circ} \mathrm{C}$ and is sensitive to temperatures below $10^{\circ} \mathrm{C}$. In mangosteen, LT (below $20^{\circ} \mathrm{C}$ ) markedly slowed down the overall growth of the tree, whereas HT (above $35^{\circ} \mathrm{C}$ ) caused some stresses on the trees [150]. Low temperatures during floral development in fruit trees result in fewer healthy flowers. On the other hand HT during floral development causes dryness and leads to sterility. Larcher [151] showed that banana, papaya, mango, grape and orange are sensitive to LT and lose their quality and productivity. Aslamarz et al. [152] studied several walnut cultivars and genotypes and found the temperature had a great influence on the performance of trees. On the basis of the heat requirements, walnut trees were classified as: low requirement, medium requirement, or high requirement. In most of the cases, HT regimes result in the best quality fruits but extremely HTs for extended periods of time are known to cause damage.

\begin{tabular}{lcc}
\hline \multicolumn{1}{c}{ Tree species } & Optimum temperature & References \\
\hline Mangifera indica & $24-27^{\circ} \mathrm{C}$ & {$[153]$} \\
\hline Litchi chinensis & $25-35^{\circ} \mathrm{C}$ & {$[149]$} \\
\hline Psidium guajava & $23-28^{\circ} \mathrm{C}$ & {$[154]$} \\
\hline Artocarpus heterophyllus & $16-28^{\circ} \mathrm{C}$ & {$[155]$} \\
\hline Dimocarpus longan & $20-25^{\circ} \mathrm{C}$ & {$[154]$} \\
\hline Durio zibethinus & $24-30^{\circ} \mathrm{C}$ & {$[154]$} \\
\hline Nephelium lappaceum & $25-32^{\circ} \mathrm{C}$ & {$[154]$} \\
\hline Musa spp. & $20-35^{\circ} \mathrm{C}$ & {$[156]$} \\
\hline Vitis vinifera & $10-35^{\circ} \mathrm{C}$ & {$[157]$} \\
\hline Cocos nucifera & $20-32^{\circ} \mathrm{C}$ & {$[158]$} \\
\hline Anacardium occidentale & $20-35^{\circ} \mathrm{C}$ & {$[159]$} \\
\hline
\end{tabular}

Table 3. Optimum temperature ranges for growth of some tropical fruit trees

\section{Oxidative stress under extreme temperature}

Oxidative stress has been mentioned as a common metabolic route of different stresses [160], and the regulation of oxidative stress has been mentioned as an indication of abiotic stress tolerance of plants by different studies [3, 161-163]. Several recent reports indicated that under abiotic stress production of free radicles or ROS markedly increased [3, 164-166]. Temperature stress accelerates the generation of ROS including singlet oxygen $\left({ }^{1} \mathrm{O}_{2}\right)$, superoxide radical $\left(\mathrm{O}_{2} \bullet-\right)$, hydrogen peroxide $\left(\mathrm{H}_{2} \mathrm{O}_{2}\right)$ and hydroxyl radical $(\mathrm{OH} \bullet)$, thereby induced oxidative stress $[10,167]$. In plant cells, ROS are continuously produced as a consequence of aerobic metabolism in all the intracellular organelles, particularly in the chloroplast, mitochondria and 
peroxisomes [160, 168; Fig. 4]. But the chloroplast is considered as the main source of ROS in plants.

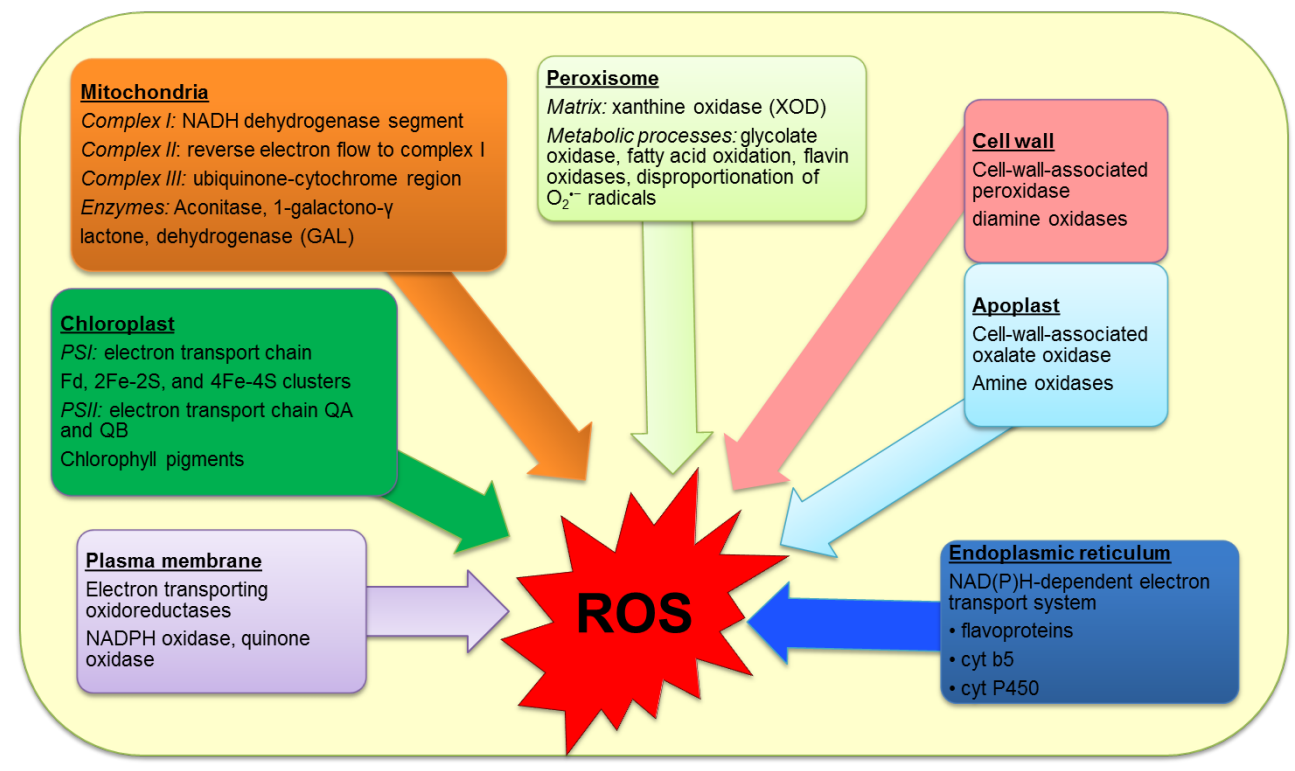

Figure 4. Sites of production of reactive oxygen species (ROS) in plants

Superoxide radical $\left(\mathrm{O}_{2}{ }^{\bullet-}\right)$ is formed in many photooxidation reactions (flavoprotein, redox cycling), Mehler reaction in chloroplasts, mitochondrial ETCs reactions, glyoxisomal photorespiration, NADPH oxidase in plasma membranes and xanthine oxidase and membrane polypeptides. Hydroxyl radical $\left(\mathrm{OH}^{\bullet}\right)$ is formed due to the reaction of $\mathrm{H}_{2} \mathrm{O}_{2}$ with $\mathrm{O}_{2}{ }^{\bullet-}($ HaberWeiss reaction), reactions of $\mathrm{H}_{2} \mathrm{O}_{2}$ with $\mathrm{Fe}^{2+}$ (Fenton reaction) and decomposition of $\mathrm{O}_{3}$ in apoplastic space $[169,170]$. Hydroxyl radicals $\left(\mathrm{OH}^{\bullet}\right)$ can potentially react with all biomolecules like, pigments, proteins, lipids and DNA, and almost with all constituent of cells. Hydroxyl radical is not considered to have signaling function although the products of its reactions can elicit signaling responses, and cells sequester the catalytic metals to metallochaperones efficiently avoiding $\mathrm{OH}^{\bullet}[169,170]$. Singlet oxygen $\left({ }^{1} \mathrm{O}_{2}\right)$ is formed during photoinhibition, and PS II electron transfer reactions in chloroplasts. This radical directly oxidizes protein, polyunsaturated fatty acids, and DNA [171, 172].

The main effects of ROS include autocatalytic peroxidation of membrane lipids and pigments, modification of membrane permeability and functions [3,173]. During the time of temperature stress, ROS level can increase dramatically which can result in significant damage to cell structure [174]. Vallelian-Bindschedler et al. [175] reported that even very short heat pulses can result in oxidative bursts of $\mathrm{O}_{2}{ }^{--}$and/or $\mathrm{H}_{2} \mathrm{O}_{2}$. Heat stress may disturb the homeostatic balance of cell and promote lipid peroxidation, either by increasing the production of reactive 
oxygen species or by decreasing the $\mathrm{O}_{2}$ radical scavenging ability in the cell [176]. The drastic increase in lipid peroxidation due to HT stress was reported by many researchers [162, 177]. Several lines of study indicated that under heat-stress conditions, malondialdehyde (MDA), a product of peroxidation of unsaturated fatty acids, has been used as a good indicator of free radical damage to cell membranes $[12,178,179]$. In wheat seedlings (8-d old) gradual increase in the accumulation of $\mathrm{H}_{2} \mathrm{O}_{2}$ was observed $\left(0.5,0.58,0.78\right.$ and $\left.1.1 \mu \mathrm{mol} \mathrm{g}{ }^{-1} \mathrm{FW}\right)$ in response to differential heat shock treatment of $22,30,35$ and $40^{\circ} \mathrm{C}$ for $2 \mathrm{~h}$ [180]. The effect of a long-term (24 h) HT $\left(42^{\circ} \mathrm{C}\right)$ shock on oxidative damages in T. aestivum seedlings was investigated by Savicka and Škute [181] in respect of the changes in $\mathrm{O}_{2}{ }^{\bullet-}$ production and MDA content. The effect of HT was analyzed at the early (4-d-old) and late stages (7-d-old) of seedling development. The increase of $\mathrm{O}_{2}{ }^{\bullet-}$ production, which was observed in the first leaf of wheat seedlings at all stages of development, led to an increase of MDA concentration. Parameter changes in the level of $\mathrm{O}_{2}{ }^{\bullet-}$ production were observed in the roots of wheat seedlings grown under HT exposure for $24 \mathrm{~h}$ at all stages of development, but MDA concentration in the roots of experimental and control seedlings did not differ significantly at the early and late stages of development. The level of $\mathrm{O}_{2}{ }^{\bullet-}$ production in coleoptile cells increased after a HT exposure at the late stages of seedling development. They concluded that growth inhibition of the root system could be connected with a powerful oxidative stress, evidenced by a significant increase $(68 \%)$ of $\mathrm{O}_{2}{ }^{\bullet-}$ production in root cells during the early stages of seedling development and an insignificant increase $(6 \%)$ of $\mathrm{O}_{2}{ }^{\bullet-}$ production $2 \mathrm{~d}$ after a HT exposure, as compared to control seedlings. The increase of $\mathrm{O}_{2}{ }^{\bullet-}$ production was also observed in roots after a HT stress during the late stages of development, and this effect was present $2 \mathrm{~d}$ after a HT exposure (6 and $42 \%$, respectively). Moreover, $\mathrm{O}_{2}{ }^{\bullet-}$ production after $2 \mathrm{~d}$ at the late stages was more intensive than at the early stages of development (79\% and $22 \%$, respectively). In contrast, in the first leaf cells at late seedling development stages a higher level of $\mathrm{O}_{2}{ }^{\bullet-}$ production was observed immediately after exposure (65\%) as compared to $2 \mathrm{~d}$ after HT exposure $(34 \%)$. The MDA content increased by $27 \%$ in the first leaf in $2 \mathrm{~d}$ after exposure at the early stages of seedling development, and this trend also continued during the late stages of development (58\%) [181]. Kumar et al. [182] observed that high temperature of $40 / 35^{\circ} \mathrm{C}$ (day/night temperature) resulted in 1.8fold increase of MDA content in rice genotypes and 1.2- to 1.3-fold increase in maize genotypes over the control treatment. At $45 / 40^{\circ} \mathrm{C}$, a further increase of MDA content was observed in both the crops, which were 2.2- to 2.4-fold increase in rice and 1.7-fold in maize genotypes compared to control. Similarly at $40 / 35^{\circ} \mathrm{C}$ the $\mathrm{H}_{2} \mathrm{O}_{2}$ level showed 1.9- to 2.0-fold elevation in rice genotypes and 1.4- to 1.6-fold elevation in maize genotypes relative to their respective controls. Moreover, at $45 / 40^{\circ} \mathrm{C}, \mathrm{H}_{2} \mathrm{O}_{2}$ content increased further in higher rate in maize genotypes.

Low temperature is also responsible for the production of ROS in plant cell [183, 184]. In extreme cold beyond the plants tolerant level or in chilling sensitive plants the activities of antioxidant enzymes are reduced which accelerate the accumulation of ROS in higher amount. Production of ROS severely affects electron transfer and biochemical reactions [12, 108]. Low temperature-induced oxidative stress decreases phospholipid content, increases lipid peroxidation, free and saturated fatty acid content [185-187]. This stress damages lipid, protein, carbohydrate and DNA [Gill SS and Tuteja 2010], thus it alters the enzyme activities, bio- 
chemical reactions and plant physiological processes including photosynthesis, respiration, nutrient movements, transpiration which negatively affect plants survival. In extreme cases ROS induced oxidative stress causes cell death [160].

However, recent studies have shown that ROS could also play a key role in mediating important signal transduction events. The rates of ROS production during temperature stress could play a central role in stress perception and protection [12].

\section{Antioxidant defense under temperature stress}

Plants have various enzymatic and non-enzymatic defense systems to minimize the deleterious effects of ROS which include the enzymes: catalase (CAT), ascorbate peroxidase (APX), monodehydroascorbate reductase (MDHAR), dehydroascorbate reductase (DHAR), glutathione reductase (GR), glutathione $S$-transferase (GST), glutathione peroxidase (GPX), superoxide dismutase (SOD) etc. as well as non-enzymatic compounds such as ascorbate (AsA), glutathione (GSH), carotenoids etc. However, under the extreme condition, ROS production overwhelm the scavenging action of the antioxidant system, which results in extensive cellular damage and death. In such cases external protectants as well as genetic manipulation of defense genes can work in upregulating the defense system which is also true for temperature stress induced oxidative damage. There are numerous plant studies which indicate the tolerance to temperature stress in plants is positively correlated with an increase in antioxidants $[3,17,18,188,189]$.

Under HT stress, plants are found to accumulate enhanced amount of non-enzymatic antioxidant and upregulate the activities of antioxidant enzymes. However, in most of the cases these enhanced activities are not sufficient for stress tolerance in plants, especially in susceptible genotypes [3, 18]. Almeselmani et al. [18] observed that the activities of SOD, APX, CAT, GR and POX were increased significantly at all stages of growth in heat-tolerant cultivars (C 306) in response to heat stress while the susceptible cultivar (PBW 343) showed a significant reduction in CAT, GR and POX activities. While investigating the induction of antioxidant enzymes (SOD, APX, GR and CAT) in wheat shoot under HT stresses, Badawi et al. [190] observed that three wheat genotypes (Fang, Siete Cerros and Imam) showed differences in their antioxidant enzyme activities. Importantly, Fang, the heat tolerant genotype, showed higher SOD, APX, GR and CAT activities under HT stress compared to the other two genotypes which indicated the role of the antioxidant defense system in conferring heat stress tolerance. Djanaguiraman et al. [86] observed that HT stress decreased antioxidant enzyme activities and increased oxidant production in sorghum. In their study, SOD, CAT and POX activities were decreased in heat stress (22, 15 and 25\% lower than control plants) and the greater inhibition of all antioxidant enzymes in heat-stressed plants relative to control plants indicates greater inactivation of all antioxidant enzymes by heat stress. On the other hand, the application of selenium (Se) decreased oxidative damages by enhancing antioxidant defense resulting in higher grain yield. In addition, the increase in antioxidant enzyme activities and decrease in ROS content by Se was greater in HT than in optimum temperature. In Cicer arietinum plants, 
Kaushal et al. [191] reported that heat stress $\left(45 / 40^{\circ} \mathrm{C}\right)$ induced the activities of enzymatic (SOD, CAT, APX, GR) and levels of non-enzymatic (AsA, GSH) antioxidants. However, the plants growing in the presence of proline reduced the oxidative injury which was coupled with elevated levels of enzymatic and non-enzymatic antioxidants which indicated the upregulation of the antioxidant defense system could imparts partial heat tolerance to chickpea plants. Recently, we investigated the effect of HT stress $\left(38^{\circ} \mathrm{C}\right.$ for 24 and $48 \mathrm{~h}$ ) on antioxidant defense system and the protective role of $\mathrm{NO}$ in coffering stress tolerance in T. aestivum L. cv. Pradip) seedlings [Hasanuzzaman et al. 2012b]. We observed that AsA content markedly decreased upon heat treatment but GSH and glutathione disulfide (GSSG) content increased. Heat treatment resulted in an increase in the activities of antioxidant enzymes - APX, GR, GPX and GST. However, supplementation of heat-treated seedlings with sodium nitroprusside (SNP) significantly increased the content of AsA and GSH as well as the GSH/GSSG ratio [165]. Heat treated seedlings which were supplemented with SNP also upregulated the activities of APX, MDHAR, DHAR, GR, GST and CAT. This study clearly indicated the role of antioxidant defense to develop stress tolerance in plant under HT. Bavita et al. [192] reported that the upregulation of the antioxidant system by $\mathrm{NO}$ possibly contributed to better tolerance against HT induced oxidative damage in wheat.

A higher AsA content was found to associate with higher antioxidative capacity and higher cold tolerance in rice [184]. Streb et al. [193] found to increase the contents of AsA and $\alpha$ tocopherol in chilling-tolerant cereal leaves which helped to maintain better photosynthesis levels as compared to the chilling sensitive varieties. Fortunato et al. [194] stated that the elevated ROS production indicated by $\mathrm{H}_{2} \mathrm{O}_{2}$ and $\mathrm{OH}^{\bullet}$ was reduced by the over production of AsA and $\alpha$-tocopherol contents under LT stress in Coffea sp. The ratio of GSH/GSSG is also important because higher of this ratio is an indication for better tolerance to stress. Under stressful condition including the cold the higher GSH/GSSG ratio is desirable for the sufficient amount of GSH in the AsA-GSH cycle [195]. Takáč et al. [196] showed that the activities of some antioxidant enzymes are partially correlated with the chilling sensitivity of maize cultivars and thus the antioxidant enzymes posses a significant importance in the chilling tolerance of Z. mays. In rice, a greater efficiency of antioxidant enzymes was observed in chilling-tolerant cultivars and the activities of those were far higher than chilling-susceptible cultivars [19]. Wang and Li [90] observed that both heat and cold altered the antioxidant defense system in grape plants. However, exogenous salicylic acid (SA) pretreatment enabled the grape leaves to maintain relatively higher activities of APX, GR, MDHAR, and redox ratio in the AsA-GSH pool both under normal temperature and heat or cold stress. They also suggested that $\mathrm{Ca}^{2+}$ homeostasis and antioxidant systems are involved in SA-induced heat or cold tolerance. Zhao et al. [189] observed that the chilling tolerance of tomato cultivars could obviously be indicated by higher activities of CAT, APX, POX and SOD. Zhang et al. [2009] found that chilling stress reduced the activities of antioxidant enzymes viz. SOD, POD, CAT and APX in C. sativus. However, these changes were significantly restored by exogenous application of putrescine (Put) and spermidine (Spd) which rendered the plants tolerant to chilling. Zhao et al. [189] reported that the chilling tolerance of tomato cultivars could obviously be designated by the higher activities of CAT, APX, POX and SOD enzyme. Chu et al. [197] observed that Se treatments significantly increased the content of anthocyanins, 
flavonoids, and phenolic compound of seedlings subjected to LT stress which was mainly due to the ability to scavenge ROS. They showed a significant increase in activities of POD and CAT in Se treated wheat seedlings under LT. Liu et al. [198] found insufficient antioxidant defense in Cucumis sativus seedlings under chilling $\left(4^{\circ} \mathrm{C}\right)$. But when the seedlings were pretreated with 1.0 mM SNP (NO donor) and exposed to LT they observed that treatment with NO donor stimulated the activities of various enzymes such as SOD, GR, POD and CAT which indicates that exogenous NO enhanced chilling stress tolerance. It was also observed that due to SNP treatment the MDA content was significantly decreased $(27 \%)$ in chilling-stressed seedlings as compared to stress alone. Yang et al. [199] observed that the enhanced activities of SOD, CAT, APX and POX in C. sativus plants reflected better tolerance to chilling. The activities of SOD, APX, GR and POX increased in cold-acclimated Cicer arietinum plants at the chilling stress of 2 and $4^{\circ} \mathrm{C}$ which enhanced their chilling tolerance [200].

\section{Conclusion and future perspectives}

The extreme temperatures those are consequences of present-day global climate changes are considered as major abiotic stresses for crop plants. Different plant studies clearly show that temperatures exceeding the limits of adaptation substantially influence the metabolism, viability, physiology, and yield of many plants. Plants exposed to extreme temperatures often show a common response in the form of oxidative stress. However, the extent of damage caused by extreme temperatures depends greatly on the duration of the adverse temperature, the genotypes of the exposed plants, and their stage of growth. There is ample need to develop temperature tolerance in crop plants by exploring suitable strategies. Numerous research findings support the notion that induction and regulation of antioxidant defenses are necessary for obtaining substantial tolerance against environmental stress. The development of genetically engineered plants, by the introduction and/or overexpression of selected genes, would to be one feasible strategy. However, plant adaptation to either HT or LT is a multigenic response which is very complex in nature. Thus the task of identifying the traits those correlate with stress tolerance is incredibly difficult for researchers.

At present, number of genes have been identified in different studies but the knowledge of the transcriptional control of extreme temperature responses is limited. In addition, the regulation of these transcriptional responses is far more complex than previously believed. In recent years, a number of exogenous protectants, such as proline, glycinebetaine, nitric oxide, silicon, selenium, salicylic acid, and polyamines have been tested and found to be beneficial in protecting plants against damage from temperature extremes. Therefore, more advanced research should conduct focusing on the development of plants those restrain genes which promote the accumulation/synthesis of these beneficial elements and compounds. Considering these facts, a well organized approach should combine to investigate the molecular, physiological, and metabolic aspects of temperature stress tolerance both at the cellular and the whole plant level. 


\section{Acknowledgements}

We wish to thank Mr. Md. Mahabub Alam, Laboratory of Plant Stress Responses, Faculty of Agriculture, Kagawa University, Japan for his vital assistance during the preparation of the manuscript.

\section{Author details}

Mirza Hasanuzzaman ${ }^{1,2}$, Kamrun Nahar ${ }^{1,3}$ and Masayuki Fujita ${ }^{1 *}$

*Address all correspondence to: fujita@ag.kagawa-u.ac.jp

*Address all correspondence to: mhzsauag@yahoo.com

1 Laboratory of Plant Stress Responses, Department of Applied Biological Science, Faculty of Agriculture, Kagawa University, Miki-cho, Kita-gun, Kagawa, Japan

2 Department of Agronomy, Faculty of Agriculture, Sher-e-Bangla Agricultural University, Sher-e-Bangla Nagar, Dhaka, Bangladesh

3 Department of Agricultural Botany, Faculty of Agriculture, Sher-e-Bangla Agricultural University, Sher-e-Bangla Nagar, Dhaka, Bangladesh

\section{References}

[1] Watanabe, T, \& Kume, T. A general adaptation strategy for climate change impacts on paddy cultivation: special reference to the Japanese context. Paddy Water Environment (2009). , 7, 313-320.

[2] Shah, F, Huang, J, Cui, K, Nie, L, Shah, T, Chen, C, \& Wang, K. Impact of hightemperature stress on rice plant and its traits related to tolerance. Journal of Agricultural Science, Cambridge (2011). , 149, 545-556.

[3] Hasanuzzaman, M, \& Hossain, M. A. Teixeira da Silva JA, Fujita M. Plant Responses and tolerance to abiotic oxidative stress: antioxidant defenses is a key factors. In: Bandi V, Shanker AK, Shanker C, Mandapaka M (eds) Crop Stress and its management: Perspectives and strategies. Berlin: Springer; (2012). , 261-316.

[4] EPAA Student's Guide to Global Climate Change. www.epa.gov;(2011).

[5] Wahid, A. Physiological implications of metabolites biosynthesis in net assimilation and heat stress tolerance of sugarcane (Saccharum officinarum) sprouts. Journal of Plant Research (2007). , 120, 219-228. 
[6] Zróbek-sokolnik, A. Temperature stress and responses of plants. In: Ahmad P, Prasad MNV (eds) Environmental adaptations and stress tolerance of plants in the era of climate change. New York: Springer; (2012). , 113-134.

[7] Mittler, R. Abiotic stress, the field environment and stress combination. Trends in Plant Science (2006). , 11, 15-19.

[8] Xin, Z, \& Browse, J. Cold comfort farm: the acclimation of plants to freezing temperatures. Plant, Cell and Environment (2000). , 23, 893-902.

[9] Sanghera, G. S, Wani, S. H, Hussain, W, \& Singh, N. B. Engineering cold stress tolerance in crop plants. Current Genomics (2011). , 12, 30-43.

[10] Mittler, R. Oxidative stress, antioxidants and stress tolerance. Trends in Plant Science (2002). , 7, 405-410.

[11] Yin, H, Chen, Q. M, \& Yi, M. F. Effects of short-term heat stress on oxidative damage and responses of antioxidant system in Lilium longiflorum. Plant Growth Regulation (2008). , 54, 45-54.

[12] Suzuki, N, \& Mittler, R. Reactive oxygen species and temperature stresses: a delicate balance between signaling and destruction. Physiologia Plantarum (2006). , 126, 45-51.

[13] Kim, K, Portis, J, \& Oxygen-dependent, $\mathrm{H} . \mathrm{O}_{2}$ production by Rubisco. FEBS Letters (2004). , 571, 124-128.

[14] Hu, W. H, Song, X. S, Shi, K, Xia, X. J, Zhou, Y. H, \& Yu, J. Q. Changes in electron transport, superoxide ismutase and ascorbate peroxidase isoenzymes in chloroplasts and mitochondria of cucumber leaves as influenced by chilling. Photosynthetica (2008). , 46, 581-588.

[15] Kotak, S, Larkindale, J, Lee, U, Von Koskull-döring, P, Vierling, E, \& Scharf, K. D. Complexity of the heat stress response in plants. Current Opinion in Plant Biology (2007). , 10, 310-316.

[16] Almeselmani, M, Deshmukh, P. S, Sairam, R. K, Kushwaha, S. R, \& Singh, T. P. Protective role of antioxidant enzymes under high temperature stress. Plant Science (2006). , 171, 382-388.

[17] Babu, N. R, \& Devraj, V. R. High temperature and salt stress response in French bean (Phaseolus vulgaris). Australian Journal of Crop Science (2008). , 2, 40-48.

[18] Almeselmani, M, Deshmukh, P. S, \& Sairam, R. K. High temperature stress tolerance in wheat genotypes: role of antioxidant defence enzymes. Acta Agronomica Hungarica (2009). , 57, 1-14.

[19] Huang, M, \& Guo, Z. Responses of antioxidant system to chilling stress in two rice cultivars differing in sensitivity. Biologia Plantarum (2005). , 49, 81-84.

[20] Prasad PVVBoote KJ, Allen Jr LH. Adverse high temperature effects on pollen viability, seed-set, seed yield and harvest index of grain-sorghum [Sorghum bicolor (L.) Moench] 
are more severe at elevated carbon dioxide due to higher tissue temperatures. Agricultural and Forest Meteorology (2006). , 139, 237-251.

[21] Saitoh, H. Ecological and physiology of vegetable. Tokyo: Nousangyoson Bunka Kyoukai; (2008).

[22] Johkan, M, Oda, M, Maruo, T, \& Shinohara, Y. Crop production and global warming. In: Casalegno S (ed) Global warming impacts- Case studies on the economy, human health, and on urban and natural environments. Rijeka: InTech; (2011). , 139-152.

[23] Roberts, E. H. Temperature and seed germination. In: Long SP, Woodward FI (eds) Plants and temperature. Symposia of the Society of Experimental Biology, Company of Biologists, Cambridge; (1988). , 109-132.

[24] Prasad PVVStaggenborg SA, Ristic Z. Impacts of drought and/or heat stress on physiological, developmental, growth, and yield processes of crop plants. In: Ahuja LH, Saseendran SA (eds) Response of crops to limited water: Understanding and modeling water stress effects on plant growth processes. Advances in Agricultural Systems Modeling Series 1. ASA-CSSA, Madison, Wisconsin; (2008). , 301-355.

[25] Essemine, J, Ammar, S, \& Bouzid, S. Impact of heat stress on germination and growth in higher plants: Physiological, biochemical and molecular repercussions and mechanisms of defence. Journal of Biological Sciences (2010). , 10, 565-572.

[26] Kumar, S, Kaur, R, Kaur, N, Bhandhari, K, Kaushal, N, Gupta, K, Bains, T. S, \& Nayyar, $\mathrm{H}$. Heat-stress induced inhibition in growth and chlorosis in mungbean (Phaseolus aureus Roxb.) is partly mitigated by ascorbic acid application and is related to reduction in oxidative stress. Acta Physiologiae Plantarum 2011; , 33, 2091-2101.

[27] Piramila BHMPrabha AL, Nandagopalan V, Stanley AL. Effect of heat treatment on germination, seedling growth and some biochemical parameters of dry seeds of black gram. International Journal of Pharmaceutical and Phytopharmacological Research (2012). , 1, 194-202.

[28] Pant, G, Malla, S, Aruna, J, \& Chauhan, U. K. Effect of dry heat treatments on viability and vigour of Cassia tora L. Seeds. Online International Journal of Biosolution (2012). , $2,58-64$.

[29] Borthwick, H. A, \& Robbins, W. W. Lettuce seed and its germination. Hilgardia (1928). , 3, 275-304.

[30] Went, F. W. The effect of temperature on plant growth. Annual Review of Plant Physiology (1953). , 4, 347-362.

[31] Stotzky, G, \& Cox, E. A. Seed germination studies in Musa II. Alternating temperature requirement for germination of Musa balbisiana. American Journal of Botany (1962). , 49, 763-770.

[32] Hall, A. E. Crop responses to environment. Boca Raton: CRC Press; (2001). 
[33] Rahman, M. M. Response of wheat genotypes to late seeding heat stress. MS Thesis. Department of Crop Botany. Bangabandhu Sheikh Mujibur Rahman Agricultural University, Gazipur, Bangladesh; (2004).

[34] Ahamed, K. U, Nahar, K, Fujita, M, \& Hasanuzzaman, M. Variation in plant growth, tiller dynamics and yield components of wheat (Triticum aestivum L.) due to high temperature stress. Advances in Agriculture \& Botanics (2010). , 2, 213-224.

[35] Al-busaidi, A, Ahmed, M, \& Chikara, J. The impact of heat and water stress conditions on the growth of the biofuel plant Jatropha curcas. International Journal of Environmental Studies (2012). , 69, 273-288.

[36] Porter, J. R, \& Gawith, M. Temperature and the growth and development of wheat: A review. European Journal of Agronomy (1999). , 10, 23-36.

[37] Ashraf, M, \& Hafeez, M. Thermotolerance of pearl millet and maize at early growth stages: growth and nutrient relations. Biologia Plantarum (2004). , 48, 81-86.

[38] Zhang, G-L, Chen, L-Y, Zhang, S-T, Zheng, H, \& Liu, G. H. Effects of high temperature stress on microscopic and ultrastructural characteristics of mesophyll cells in flag leaves of rice. Rice Science (2009). , 16, 65-71.

[39] Fitter, A. H. Hay RKM. Environmental physiology of plants, 3rd edn. London: Academic Press; (2002).

[40] Schuster, W. S, \& Monson, R. K. An examination of the advantages of C3-C4 intermediate photosynthesis in warm environments. Plant, Cell \& Environment (1990). , 13, 903-912.

[41] Tan, W, Meng, Q. W, Brestic, M, Olsovska, K, \& Yang, X. Photosynthesis is improved by exogenous calcium in heat-stressed tobacco plants. Journal of Plant Physiology $2011 ;, 168,2063-2071$.

[42] Prasad PVVPisipati SR, Momčilović I, Ristic Z. Independent and combined effects of high temperature and drought stress during grain filling on plant yield and chloroplast EF-Tu Expression in spring wheat. Journal of Agronomy Crop Science (2011). , 197, 430-441.

[43] Haldimann, P, \& Feller, U. Inhibition of photosynthesis by high temperature in oak (Quercus pubescens L.) leaves grown under natural conditions closely correlates with a reversible heat-dependent reduction of the activation state of ribulose-1,5-bisphosphate carboxylase/oxygenase. Plant, Cell \& Environment (2004). , 27, 1169-1183.

[44] Eamus, D, \& Taylor, D. T. Macinnis CMO, Shanahan S, De Silva L. Comparing model predictions and experimental data for the response of stomatal conductance and guard cell turgor to manipulations of cuticular conductance, leaf-to-air vapour pressure difference and temperature: feedback mechanisms are able to account for all observations. Plant, Cell \& Environment (2008). , 31, 269-277. 
[45] Greer, D. H, \& Weston, C. Heat stress affects flowering, berry growth, sugar accumulation and photosynthesis of Vitis vinifera cv. Semillon grapevines grown in a controlled environment. Functional Plant Biology (2010). , 37, 206-214.

[46] Greer, D. H, \& Weedon, M. M. Modelling photosynthetic responses to temperature of grapevine (Vitis vinifera cv. Semillon) leaves on vines grown in a hot climate. Plant, Cell \& Environment (2012). , 35, 1050-1064.

[47] Tewari, A. K, \& Tripathy, B. C. Temperature-stress-induced impairment of chlorophyll biosynthetic eactions in cucumber and wheat. Plant Physiology (1998). , 117, 851-858.

[48] Reda, F. Mandoura HMH. Response of enzymes activities, photosynthetic pigments, proline to low or high temperature stressed wheat plant (Triticum aestivum L.) in the presence or absence of exogenous proline or cysteine. International Journal of Academic Research (2011). , 3, 108-115.

[49] Langjun CULJianlong LI, Yamin FAN, Sheng XU, Zhang Z. High temperature effects on photosynthesis, PS II functionality and antioxidant activity of two Festuca arundinacea cultivars with different heat susceptibility. Botanical Studies (2006). , 47, 61-69.

[50] Aien, A, Khetarpal, S, \& Pal, M. Photosynthetic characteristics of potato cultivars grown under high temperature. American-Eurasian Journal of Agricultural \& Environmental Sciences (2011). , 11, 633-639.

[51] Almeselmani, M, Deshmukh, P. S, \& Chinnusamy, V. Effects of prolonged high temperature stress on respiration, photosynthesis and gene expression in wheat (Triticum aestivum L.) varieties differing in their thermotolerance. Plant Stress (2012). , 6, 25-32.

[52] Malgorzata, B, Nevena, S, Zlatko, Z, \& Daniela, G. Physiological response of some tomato genotypes (Lycopersicon esculentum L.) to high temperature stres. Journal of Central European Agriculture (2009). , 9, 723-732.

[53] Wolf, S, Marani, A, \& Rudich, J. Effects of temperature and photoperiod on assimilate partitioning in potato plants. Annals of Botany (1990). , 66, 513-520.

[54] Haldimann, P, \& Feller, U. Growth at moderately elevated temperature alters the physiological response of the photosynthetic apparatus to heat stress in pea (Pisum sativum L.) leaves. Plant, Cell \& Environment (2005). , 28, 302-317.

[55] Suwa, R, Hakata, H, Hara, H, Shemy, H. A, Adu-gyamfi, J. J, Nguyen, N. T, Kanai, S, Lightfoot, D. A, Mohapatra, P. K, \& Fujita, K. High temperature effects on photosynthetic partitioning and sugar metabolism during ear expansion in maize (Zea mays L.) genotypes. Plant Physiology and Biochemistry (2010). , 48, 124-130.

[56] Mazorra, L. M, Nunez, M, Echerarria, E, Coll, F, \& Sánchez-blanco, M. J. Influence of brassinosteriods and antioxidant enzymes activity in tomato under different temperatures. Plant Biology (2002). , 45, 593-596. 
[57] Kolb, P. F, \& Robberecht, R. High temperature and drought stress effects on survival of Pinus ponderosa seedlings. Tree Physiology (1996). , 16, 665-672.

[58] Machado, S, \& Paulsen, G. M. Combined effects of drought and high temperature on water relations of wheat and sorghum. Plant and Soil (2001). , 233, 179-187.

[59] Morales, D, \& Rodriguez, P. Dell'amico J, Nicolas E, Torrecillas A, Sanchez-Blanco MJ. High temperature pre-conditioning and thermal shock imposition affects water relations, gas exchange and root hydraulic conductivity in tomato. Biologia Plantarum (2003). , 47, 203-208.

[60] Bañon, S, Fernandez, J. A, Franco, J. A, Torrecillas, A, Alarcon, J. J, \& Sánchez-blanco, M. J. Effects of water stress and night temperature preconditioning on water relations and morphological and anatomical changes of Lotus creticus plants. Scientia Horticulturae (2004). , 101, 333-342.

[61] Wahid, A, \& Close, T. J. Expression of dehydrins under heat stress and their relationship with water relations of sugarcane leaves. Biologia Plantarum (2007). , 51, 104-109.

[62] Gebbing, T, Schnyder, H, \& Kühbauch, W. The utilization of pre-anthesis reserves in grain filling of wheat. Assessment by teady-state ${ }^{13} \mathrm{CO}_{2} /{ }^{12} \mathrm{CO}_{2}$ labelling. Plant, Cell \& Environment (1999). , 22, 851-858.

[63] Morita, S, Shiratsuchi, H, Takanashi, J, \& Fujita, K. Effect of high temperature on grain ripening in rice plant. Analysis the effect on high night and high day temperatures applied to the panicle and other parts of the plant. Japanese Journal of Crop Science (2004). , 73, 77-83.

[64] Kim, J, Shon, J, Lee, C, Yang, W, Yoon, Y, Yang, W, Kim, Y, \& Lee, B. W. Relationship between grain filling duration and leaf senescence of temperate rice under high temperature. Field Crops Research (2011). , 22, 207-213.

[65] Mohapatta, P, Sarkar, R, \& Kuanar, S. Starch synthesizing enzymes and sink strength of grains of rice cultivars. Plant Science (2009). , 176, 256-263.

[66] Tang, T, Xie, H, Wang, Y, Lü, B, \& Liang, J. The effect of sucrose and abscisic acid interaction on sucrose synthase and its relationship to grain filling of rice (Oryza sativa L.). Journal of Experimental Botany (2009). , 60, 2641-2652.

[67] Morita, S, Yonermaru, J, \& Takahashi, J. Grain growth and endosperm cell size under high night temperature in rice (Oryza sativa L.). Annals of Botany (2005). , 95, 695-701.

[68] Craufurd, P. Q. Prasad PVV, Summerfield RJ. Dry matter production and rate of change of harvest index at high temperature in peanut. Crop Science (2002). , 42, 46-151.

[69] Wahid, A, Gelani, S, Ashraf, M, \& Foolad, M. R. Heat tolerance in plants: An overview. Environmental and Experimental Botany (2007). , 61, 199-223.

[70] Proctor JTAPalmer JW, Follett JM. Growth, dry matter partitioning and photosynthesis in North American ginseng seedlings. Journal of Ginseng Research (2010). , 34, 175-182. 
[71] Mckee, J, \& Richards, A. J. The effect of temperature on reproduction in five Primula species. Annals of Botany (1998). , 82, 359-374.

[72] Abdul-baki, A. A, \& Stommel, J. R. Pollen viability and fruit-set of tomato genotypes under optimum-temperature and high-temperature regimes. HortScience (1995). , 30, 115-117.

[73] Gross, Y, \& Kigel, J. Differential sensitivity to high temperature of stages in the reproductive development of common bean (Phaseolus vulgaris L.). Field Crops Research (1994). , 36, 201-212.

[74] Kozai, N, Beppu, K, Mochioka, R, Boonprakob, U, Subhadrabandhu, S, \& Kataoka, I. Adverse effects of high temperature on the development of reproductive organs in 'Hakuho' peach trees. Journal of Horticultural Science and Biotechnology (2004). , 79, 533-537.

[75] Sato, S, Peet, M. M, \& Thomas, J. F. Physiological factors limit fruit set of tomato (Lycopersicon esculentum Mill.) under chronic, mild heat stress. Plant, Cell \& Environment (2000). , 23, 719-726.

[76] Prasad PVVCraufurd PQ, Kakani VG, Wheeler TR, Boote KT. Influence of high temperature during pre- and post-anthesis stages of floral development on fruit-set and pollen germination in peanut. Australian Journal of Plant Physiology (2001). , 28, 233-240.

[77] Porch, T. G, \& Jahn, M. Effects of high temperature stress on microsporogenesis in heatsensitive and heat-tolerant genotypes of Phaseolus vulgaris. Plant, Cell \& Environment (2001). , 24, 723-731.

[78] Kitano, M, Saitoh, K, \& Kuroda, T. Effect of high temperature on flowering and pod set in soybean. Scientific Report of the Faculty of Agriculture, Okayama University (2006)., 95, 49-55.

[79] Zakaria, S, Matsuda, T, Tajima, S, \& Nitta, Y. Effect of high temperature at ripening stage on the reserve accumulation in seed in some rice cultivars. Plant Production Science (2002). , 5, 160-168.

[80] Peng, S, Huang, J, Sheehy, J. E, Laza, R. C, Visperas, R. M, Zhong, X, Centeno, G. S, Khush, G. S, \& Cassman, K. G. Rice yields decline with higher night temperature from global warming. Proceedings of the National Academy of Sciences, USA (2004). , 101, 9971-9975.

[81] Ledesma, N. A, Nakata, M, \& Sugiyama, N. Effect of high temperature stress on the reproductive growth of strawberry cvs. 'Nyoho' and 'Toyonoka'. Scientia Horticulturae (2008). , 116, 186-193.

[82] Mendham, N. J, \& Salsbury, P. A. Physiology, crop development, growth and yield. In: Kimber DS, McGregor DI (eds), Brassica oilseeds: Production and utilization. London: CABI; (1995). , 11-64. 
[83] Commuri, P. D, \& Jones, R. J. High temperatures during endosperm cell division in maize: A genotypic comparison under in vitro and field conditions. Crop Science (2001). , 41, 1122-1130.

[84] Shah, N. H, \& Paulsen, G. H. Interaction of drought and high temperature on photosynthesis and grain filling of wheat. Plant and Soil (2003). , 257, 219-226.

[85] Monjardino, P, Smith, A. G, \& Jones, R. J. Heat stress effects on protein accumulation of maize endosperm. Crop Science (2005). , 45, 1203-1210.

[86] Djanaguiraman, M. Prasad PVV, Seppanen M. Selenium protects sorghum leaves from oxidative damage under high temperature stress by enhancing antioxidant defense system. Plant Physiology and Biochemistry (2010). , 48, 999-1007.

[87] Mohammed, A. R, \& Tarpley, L. Effects of high night temperature and spikelet position on yield-related parameters of rice (Oryza sativa L.) plants. European Journal of Agronomy (2010). , 33, 117-123.

[88] Gan, Y, Wang, J, Angadi, S. V, \& Mcdonald, C. L. Response of chickpea to short periods of high temperature and water stress at different developmental stages. 4th International Crop Science Congress; (2004).

[89] Gan, Y, Angadi, S. V, Cutforth, H, Potts, D, Angadi, V. V, \& Mcdonald, C. L. Canola and mustard response to short periods of temperature and water stress at different developmental stages. Canadian Journal of Plant Science (2004). , 84, 697-704.

[90] Wang, L. J, \& Li, S. H. Salicylic acid-induced heat or cold tolerance in relation to $\mathrm{Ca}^{2+}$ homeostasis and antioxidant systems in young grape plants. Plant Science (2006). , 170, 685-694.

[91] Rahman, M. A, Chikushi, J, \& Yoshida, S. Karim AJMS. Growth and yield components of wheat genotypes exposed to high temperature stress under control environment. Bangladesh Journal of Agricultural Research (2009). , 34, 361-372.

[92] Lin, C, Li, C, Lin, S, Yang, F, Huang, J, Liu, Y, \& Lur, H. Influence of high temperature during grain filling on the accumulation of storage proteins and grain quality in rice (Oryza sativa L.). Journal of Agriculture and Food Chemistry (2010). , 58, 10545-10552.

[93] Islam, M. T. Effect of temperature on photosynthesis, yield attributes and yield of aromatic rice genotypes. Internal Journal of Sustainable Crop Production (2011). , 6, 14-16.

[94] Saha, S. R, Hossain, M. M, Rahman, M. M, Kuo, C. G, \& Abdullah, S. Effect of high temperature stress on the performance of twelve Sweet Pepper genotypes. Bangladesh Journal of Agricultural Research (2010). , 35, 525-534.

[95] Kim, Y. G, \& Lee, B. W. Relationship between grain filling duration and leaf senescence of temperate rice under high temperature. Field Crops Research (2011). , 122, 207-213. 
[96] Aroca, R, Vernieri, P, Irigoyen, J. J, Sánchez-díaz, M, Tognoni, F, \& Pardossi, A. Involvement of abscisic acid in leaf and root of maize (Zea mays L.) in avoiding chillinginduced water stress. Plant Science (2003). , 165, 671-679.

[97] Farooq, M, Aziz, T, Wahid, A, \& Lee, D. J. Siddique KHM. Chilling tolerance in maize: agronomic and physiological approaches. Crop \& Pasture Science (2009). , 60, 501-516.

[98] Nahar, K, Hasanuzzaman, M, \& Majumder, R. R. Effect of low temperature stress in transplanted Aman Rice Varieties mediated by different transplanting dates. Academic Journal of Plant Sciences (2009). , 2, 132-138.

[99] Nahar, K, \& Biswas, J. K. Shamsuzzaman AMM, Hasanuzzaman M, Barman HN. Screening of indica rice (Oryza sativa L.) genotypes against low temperature stress. Botany Research International (2009). , 2, 295-303.

[100] Zhou-fei, W, Jian-fei, W, Fu-hua, W, Yong-mei, B, Yun-yu, W, \& Hong-sheng, Z. Genetic control of germination ability under cold stress in rice. Rice Science (2009). , 16, 173-180.

[101] Yoshida, S. Physiological analysis of rice yield. Fundamentals of rice crop science. Los Banos: International Rice Research Institute; (1981). , 231-251.

[102] Nahar, K, \& Biswas, J. K. Shamsuzzaman AMM. Cold stress tolerance in rice plant: Screening of genotypes based on morphophysiological traits. Berlin: LAP Lambert Academic; (2012).

[103] Angadi, S. V, \& Cutforth, H. W. McConkey. Seeding management to reduce temperature stress in Brassica species. Saskatchewan Soils and Crops Proceedings; (2000).

[104] Buriro, M, Oad, F. C, Keerio, M. I, Tunio, S, \& Gandahi, A. W. Hassan SWU, Oad SM. Wheat seed germination under the influence of temperature regimes. Sarhad Journal of Agriculture (2011). , 27, 539-543.

[105] Krzyzanowski, F. C, \& Delouche, J. C. Germination of cotton seed in relation to temperature. Revista Brasileira de Sementes (2011). , 33, 543-548.

[106] Zabihi-e-mahmoodabad, R, Jamaati-e-somarin, S, Khayatnezhad, M, \& Gholamin, R. Effect of cold stress on germination and growth of wheat cultivars. Advances in Environmental Biology (2011). , 5, 94-97.

[107] Chinnusamy, V, Zhu, J, \& Zhu, J. K. Cold stress regulation of gene expression in plants. Trends in Plant Science (2007). , 12, 444-451.

[108] Solanke, A. U, \& Sharma, A. K. Signal transduction during cold stress in plants. Physiology and Molecular Biology of Plants (2008). , 14, 69-79.

[109] Jiang, Q. W, Kiyoharu, O, \& Ryozo, I. Two novel mitogen-activated protein signaling components, OsMEK1 and OsMAP1, are involved in a moderate low-temperature signaling pathway in Rice. Plant Physiology (2002). , 129, 1880-1891.

[110] Takeoka, Y, Mamun, A. A, Wada, T, \& Kanj, B. P. Reproductive adaptation of rice to environmental stress. Japan Sci Soc Press. Tokyo, Japan; (1992). , 8-10. 
[111] Kratsch, H. A, \& Wise, R. R. The ultrastructure of chilling stress. Plant, Cell \& Environment (2000). , 23, 337-350.

[112] Murphy, C, \& Wilson, J. M. Ultrastructural features of chilling injury in Episcia reptans. Plant, Cell Environment (1981). , 4, 261-265.

[113] Ishikawa, H. A. Ultrastructural features of chilling injury: injured cells and the early events during chilling of suspension cultured mung bean cells. American Journal of Botany (1996). , 83, 825-835.

[114] Sharma, P, Sharma, N, \& Deswal, R. The molecular biology of the low-temperature response in plants. BioEssays (2005). , 27, 1048-1059.

[115] Nishiyama, I. Damage due to extreme temperatures. In: Matsuo T, Kumazawa K, Ishii R, Ishihara H, Hirata H (Eds.) Science of the Rice Plant. Food and Agriculture Policy Research Center, Tokyo, Japan; (1995). , 769-812.

[116] Thakur, P, Kumara, S, Malika, J. A, Bergerb, J. D, \& Nayyar, H. Cold stress effects on reproductive development in grain crops: An overview. Environmental and Experimental Botany (2010). , 67, 429-443.

[117] Nelson, J. M, \& Palzkill, D. A. Irrigation effects on growth, cold tolerance of flower buds, and seed yield of jojoba. In: Janick J, Simon JE (eds.) New crops. Wiley, New York; (1993). , 360-362.

[118] Farrell, T. C, Fukai, S, \& Williams, R. L. Minimizing cold damage during reproductive development among temperate rice genotypes. I. Avoiding low temperature with the use of appropriate sowing time and photoperiod-sensitive varieties. Australian Journal of Agricultural Research (2006). , 57, 75-88.

[119] Miller, P, Lanier, W, \& Brandt, S. Using growing degree days to predict plant stages. Montana State University Extension Service; (2001).

[120] Kalisz, A, \& Cebula, S. Direct plant covering and soil mulching in the spring production of some Chinese cabbage cultivars. Effect of temperature on premature bolting. Folia Horticulturae (2001). , 13, 13-22.

[121] Steponkus, P. L, Uemura, M, Joseph, R. A, Gilmour, S. J, \& Thomashow, M. F. Mode of action of the COR15a gene on the freezing tolerance of Arabidopsis thaliana. Proceedings of the National Academy of Sciences, USA (1998). , 95, 14570-14575.

[122] Thomashow, M. F. So what's new in the field of plant cold acclimation? Lots! Plant Physiology (2001). , 125, 89-93.

[123] Mckersie, B. D, \& Bowley, S. R. Active oxygen and freezing tolerance in transgenic plants. In: Li PH, Chen THH (eds) Plant Cold Hardiness, Molecular Biology, Biochemistry and Physiology. Plenum Press: New York; (1997). , 203-214.

[124] Olien, C. R, \& Smith, M. N. Ice adhesions in relation to freeze stress, Plant Physiology (1997). , 60, 499-503. 
[125] Allen, D. J, \& Ort, D. R. Impacts of chilling temperatures on photosynthesis in warmclimate plants. Trends in Plant Science (2001). , 6, 36-42.

[126] Strand, A, Foyer, C. H, Gustafsson, P, \& Hurry, V. Increased expression of sucrosephosphate synthase in transgenic Arabidopsis thaliana results in improved photosynthetic performance and increased freezing tolerance al low temperatures. Plant, Call \& Environment (2003). , 26, 523-535.

[127] Yordanova, R, \& Popova, L. Effect of exogenous treatment with salicylic acid on photosynthetic activity and antioxidant capacity of chilled wheat plants. General and Applied Plant Physiology (2007). , 33, 155-170.

[128] Ramalho, J. C, Quartin, V. L, Leitão, E, \& Campos, P. S. Carelli MLC, Fahl JI, Nunes MA. Cold acclimation ability and photosynthesis among species of the tropical Coffea genus. Plant Biology (2003). , 5, 631-641.

[129] Silva, E. A, Damatta, F. M, Ducatti, C, Regazzi, A. J, \& Barros, R. S. Seasonal changes in vegetative growth and photosynthesis of Arabica coffee trees. Field Crops Research (2004).

[130] Partelli, F. L, Vieira, H. D, \& Viana, A. P. Batista-Santos P, Rodrigues AP, Leitão AE, Ramalho JC. Low temperature impact on photosynthetic parameters of coffee genotypes. Pesquisa Agropecuária Brasileira (2009). , 44, 1404-1415.

[131] Aghaee, A, Moradi, F, Zare-maivan, H, Zarinkamar, F, Irandoost, H. P, \& Sharifi, P. Physiological responses of two rice (Oryza sativa L.) genotypes to chilling stress at seedling stage. African Journal of Biotechnology (2011). , 10, 7617-7621.

[132] Salinas, J. Molecular mechanisms of signal transduction in cold acclimation. In: Scheel D, Wasternack C (eds) Plant signal transduction. London: Oxford University Press; (2002). , 116-139.

[133] Mahajan, S, \& Tuteja, N. Cold, salinity and drought stresses: An overview. Archives of Biochemistry and Biophysics (2005). , 444, 139-158.

[134] Yadav, S. K. Cold stress tolerance mechanisms in plants. A review. Agronomy for Sustainable Development (2010). , 30, 515-527.

[135] Thomashow, M. F. Plant cold acclimation: freezing tolerance genes and regulatory mechanisms. Annual Review of Plant Physiology and Plant Molecular Biology (1999). , $50,571-579$.

[136] Enns, L. C, Mccully, M. E, \& Canny, M. J. Branch roots of young maize seedlings, their production, growth, and phloem supply from the primary root. Functional Plant Biology (2006). , 33, 391-399.

[137] Lee, H, Guo, Y, Ohta, M, Xiong, L, Stevenson, B, \& Zhu, J. K. LOS2, a genetic locus required for cold responsive transcription encodes a bi-functional enolase. EMBO Journal (2002). , 21, 2692-2702. 
[138] Matzner, S, \& Comstock, J. The temperature dependence of shoot hydraulic resistance: implications for stomatal behaviour and hydraulic limitation. Plant, Cell \& Environment (2001). , 24, 1299-1307.

[139] Hurry, V. M, Malmberg, G, Gardestorm, P, \& Oquist, G. Effects of a short term shift to low temperature and of long term cold hardening on photosynthesis and ribulose-1, 5bisphosphate carboxylase/oxygenase and sucrose phosphate activity in leaves of winter rye (Secale cereale L.). Plant Physiology (1994). , 106, 983-990.

[140] Kalbarczyk, R. Potential reduction in cucumber yield (Cucumis sativus 1.) in poland caused by unfavourable thermal conditions of soil. Acta Scientiarum Polonorum Hortorum Cultus (2009). , 8, 45-58.

[141] Riaz-ud-dinSubhani GM, Ahmad N, Hussain M, Rehman AU. Effect of temperature on development and grain formation in spring wheat. Pakistan Journal of Botany (2010). , 42, 899-906.

[142] Andaya, V. C, \& Mackill, D. J. QTLs conferring cold tolerance at the booting stage of rice using recombinant inbred lines from a japonica $\times$ indica cross. Theoretical and Applied Genetics (2003).

[143] Korkmaz, A, \& Dufault, R. J. Short-term cyclic cold temperature stress on water melon yield. HortScience (2002). , 37, 487-489.

[144] Whiley, A. W, Rasmussen, T. S, Saranah, J. B, \& Wolstenholme, B. N. Effect of temperature on growth, dry matter production and starch accumulation in ten mango (Mangifera indica L.) cultivars. Journal of Horticultural Science and Biotechnology (1989). , 64, 753-765.

[145] Dinesh, M. R. Reddy BMC. Physiological basis of growth and fruit yield characteristics of tropical and Sub-tropical fruits to temperature. In: Sthapit BR, Ramanatha Rao V, Sthapit S (eds) Tropical fruit tree species and climate change. Biodiversity International: New Delhi; (2012).

[146] Mukherjee, S. K. The mango-its botany, cultivation, uses and future improvement, especially observed in India. Economic Botany (1953). , 7, 130-162.

[147] Schaffer, B, Urban, L, Lu, P, \& Whiley, A. W. Ecophysiology. In: Litz RE (eds) The Mango Botany, Production and Uses. CABI: London; (2009).

[148] Yang, Y-H, Zhu, X-C, Wang, S-C, Hu, G-B, Hee, H, \& Huang, X-M. Developmental problems in over-winter offseason longan fruit. I: Effect of temperature. Scientia Horticulturae (2010). , 126, 351-358.

[149] Tindall, H. D. Rambutan Cultivation. Food and Agriculture Organization of the United Nations. FAO: Rome; (1994). 978-9-25103-325-8

[150] Rejab, M, Teck, C. S, Zain, K. M, \& Muhamad, M. Mangosteen. In: Kwok CY, Lian TS, Jamaluddin SH (eds) Breeding Horticultural Crops. MARDI: Kuala Lumpur; (2008). , 155-174. 
[151] Larcher, W. Physiological Plant Ecology-Ecophysiology and Stress Physiology of Functional Groups. Berlin: Springer; (1995).

[152] Aslamarz, A. A, Vahdati, K, \& Rahemi, M. Estimation of chilling and heat requirements of some persian walnut cultivars and genotypes. HortScience (2009). , 44, 3-697.

[153] Davanport, T. L. Reproductive physiology. In: Litz RE (ed) The Mango, 2nd edn. Botany, Production and Uses. CABI: London; (2009).

[154] Verheij EWMCoronel RE. Edible fruits and nuts. Plant Resources of South-East Asia Prosea Foundation: Bogor; (1992). (2), 128-131.

[155] Haq, N. Fruits for the Future 10. Jackfruit (Artocarpus heterophyllus) Southampton Centre for Underutilised Crops; (2006). , 192.

[156] Viktorova, M. K. Plant growing in the tropics and subtropics. Mir publisher:, Moscow; (1983). , 214-218.

[157] White, M. A, Diffenbaugh, N. S, Jones, G. V, Pal, J. S, \& Giorgi, F. Extreme heat reduces and shifts United States premium wine production in the 21st Century. Proceedings of the National Academy of Sciences (2006). , 103, 11217-11222.

[158] Louis, H, \& Annappan, R. S. Indian Coconut Journal (1980). , 10, 1-3.

[159] Joubert, A. S. Thomas DDS. Farming South Africa (1965). , 40, 6-7.

[160] Apel, K, \& Hirt, H. Reactive oxygen species: metabolism, oxidative stress and signal transduction. Annual Review of Plant Biology (2004). , 55, 373-399.

[161] Ashraf, M. Biotechnological approach of improving plant salt tolerance using antioxidants as markers. Biotechnol Advances (2009). , 27, 84-93.

[162] Hasanuzzaman, M, Nahar, K, Alam, M. M, \& Fujita, M. Exogenous nitric oxide alleviates high temperature induced oxidative stress in wheat (Triticum aestivum L.) seedlings by modulating the antioxidant defense and glyoxalase system. Australian Journal of Crop Science (2012). , 6, 1314-1323.

[163] Hasanuzzaman, M, Hossain, M. A, \& Fujita, M. Exogenous selenium pretreatment protects rapeseed seedlings from cadmium-induced oxidative stress by up-regulating the antioxidant defense and methylglyoxal detoxification systems. Biological Trace Element Research (2012). doi:s12011-012-9419-4.

[164] Hasanuzzaman, M, Hossain, M. A, \& Fujita, M. Nitric oxide modulates antioxidant defense and methylglyoxal detoxification system and reduces salinity-induced damage in wheat seedling. Plant Biotechnology Reports (2011). , 5, 353-365.

[165] Hasanuzzaman, M, Hossain, M. A, \& Fujita, M. Selenium-induced up-regulation of the antioxidant defense and methylglyoxal detoxification system reduces salinity-induced damage in rapeseed seedlings. Biological Trace Element Research (2011). , 143, 1704-1721. 
[166] Hasanuzzaman, M, \& Fujita, M. Selenium pretreatment upregulates the antioxidant defense and methylglyoxal detoxification system and confers enhanced tolerance to drought stress in rapeseed seedlings. Biological Trace Element Research (2011). , 143, 1758-76.

[167] Potters, G, Pasternak, T. P, Guisez, Y, \& Palme, K. J. Jansen MAK. Stress-induced morphogenic responses: growing out of trouble. Trends in Plant Science (2007). , 12, 98-105.

[168] Sharma, P, Jha, A. B, Dubey, R. S, \& Pessarakli, M. Reactive oxygen species, oxidative damage, and antioxidative defense mechanism in plants under stressful conditions. Journal of Botany (2012). doi:10.1155/2012/217037.

[169] Halliwell, B. Oxidative stress and neurodegeneration: where are we now? Journal of Neurochemistry (2006). , 97, 1634-1658.

[170] Moller, I. M, Jensen, P. E, \& Hansson, A. Oxidative modifications to cellular components in plants. Annual Review of Plant Biology (2007). , 58, 459-481.

[171] Karuppanapandian, T, Wang, H. W, Prabakaran, N, Jeyalakshmi, K, Kwon, M, Manoharan, K, \& Kim, W. dichlorophenoxyacetic acid-induced leaf senescence in mung bean (Vigna radiata L. Wilczek) and senescence inhibition by co-treatment with silver nanoparticles. Plant Physiology and Biochemistry (2011). , 49, 168-177.

[172] Karuppanapandian, T, Moon, J-C, Kim, C, Manoharan, K, \& Kim, W. Reactive oxygen species in plants: their generation, signal transduction, and scavenging mechanisms. Australian Journal of Crop Science (2011). , 5, 709-725.

[173] Xu, S, Li, J, Zhang, X, Wei, H, \& Cui, L. Effects of heat acclimation pretreatment on changes of membrane lipid peroxidation, antioxidant metabolites, and ultrastructure of chloroplasts in two cool-season turfgrass species under heat stress. Environmental and Experimental Botany (2006). , 56, 274-285.

[174] Mittler, R, Vanderauwera, S, Gollery, M, \& Van Breusegem, F. Reactive oxygen gene network of plants. Trends in Plant Science (2004). , 9, 490-498.

[175] Vallelian-bindschedler, L, Schweizer, P, Mosinger, E, \& Metraux, J. P. Heat-induced resistance in barley to powdery mildew (Blumeria graminis f. sp. hordei) is associated with a burst of active oxygen species. Molecular Plant Pathology (1998). , 52, 185-199.

[176] Bowler, C, Vanmontagu, B, \& Inze, D. Superoxide dismutase and stress tolerance. Annual Review of Plant Physiology and Plant Molecular Biology (1992). , 43, 83-116.

[177] Wu, B, Jiang, Q. W, Gu, T. T, Zhao, M, \& Liu, L. W. Physiological response to high temperature stress in radish seedlings with different heat tolerance. China Vegetables (2010). doi:CNKI:SUN:ZGSC.0.2010-10-007.

[178] Liu, X, \& Huang, B. Heat stress injury in relation to membrane lipid peroxidation in creeping bentgrass. Crop Science (2000). , 40, 503-510. 
[179] Tommasino, E, Griffa, S, Grunberg, K, \& Ribotta, A. López Colomba E, Carloni E, Quiroga M, Luna CM. Malondialdehyde content as a potential biochemical indicator of tolerant Cenchrus ciliaris L. genotypes under heat stress treatment. Grass and Forage Science (2012). doi:j.x., 1365-2494.

[180] Kumar, R. R, Goswami, S, Sharma, S. K, Singh, K, Gadpayle, K. A, Kumar, N, Rai, G. K, Singh, M, \& Rai, R. D. Protection against heat stress in wheat involves change in cell membrane stability, antioxidant enzymes, osmolyte, $\mathrm{H}_{2} \mathrm{O}_{2}$ and transcript of heat shock protein. International Journal of Plant Physiology and Biochemistry (2012a). , 4, 83-91.

[181] Savicka, M, \& Škute, N. Effects of high temperature on malondialdehyde content, superoxide production and growth changes in wheat seedlings (Triticum aestivum L.). Ekologija (2010). , 56, 26-33.

[182] Kumar, S, Gupta, D, \& Nayyar, H. Comparative response of maize and rice genotypes to heat stress: status of oxidative stress and antioxidants. Acta Physiologiae Plantarum (2012). , 34, 75-86.

[183] Hasegawa, P. M, \& Bressan, J. K. Zhu HJ Bohnert. Plant cellular and molecular responses to high salinity. Annual Review of Plant Physiology (2000). , 51, 463-499.

[184] Guo, Y. P, Zhou, H. F, \& Zhang, L. Photosynthetic characteristics and protective mechanisms against photooxidation during high temperature stress in two citrus species. Scientia Horticulturae (2006). , 108, 260-267.

[185] Mo, Y, Liang, G, Shi, W, \& Xie, J. Metabolic responses of alfalfa (Medicago Sativa L.) leaves to low and high temperature induced stresses. African Journal of Biotechnology (2010). , 10, 1117-1124.

[186] Sato, Y, Masuta, Y, Saito, K, Murayama, S, \& Ozawa, K. Enhanced chilling tolerance at the booting stage in rice by transgenic overexpression of the ascorbate peroxidase gene, OsAPXa. Plant Cell Reports (2011). , 30, 399-406.

[187] Chen, K, \& Arora, R. Dynamics of the antioxidant system during seed osmopriming, post-priming germination, and seedling establishment in spinach (Spinacia oleracea). Plant Science (2011). , 180, 212-220.

[188] Gill, S. S, \& Tuteja, N. Reactive oxygen species and antioxidant machinery in abiotic stress tolerance in crop plants. Plant Physiology and Biochemistry (2010). , 48, 909-930.

[189] Zhao, D. Y, Shen, L, Yu, M. M, Zheng, Y, \& Sheng, J. P. Relationship between activities of antioxidant enzymes and clod tolerance of postharvest tomato fruits. Food Science (2009). , 14, 309-313.

[190] Badawi, G. H. Tahir ISA, Nakata N, Tanaka K. Induction of some antioxidant enzymes in selected wheat genotypes. African Crop Science Conference Proceeding (2007). , 8, 841-848.

[191] Kaushal, N, Gupta, K, Bhandhari, K, Kumar, S, \& Thakur, P. Nayyar. Proline induces heat tolerance in chickpea (Cicer arietinum L.) plants by protecting vital enzymes of 
carbon and antioxidative metabolism. Physiology and Molecular Biology of Plants (2011). , 17, 203-213.

[192] Bavita, A, Shashi, B, \& Navtej, S. B. Nitric oxide alleviates oxidative damage induced by high temperature stress in wheat. Indian Journal of Experimental Biology (2012). , 50, 372-378.

[193] Streb, P, Shang, W, \& Feierabend, J. Resistance of cold-hardened winter rye leaves (Secale cereale L.) to photo-oxidative stress, Plant, Cell \& Environment (1999). , 22, 1211-1223.

[194] Fortunato, A. S, Lidon, F. C, Batista-santos, P, Leitào, A. E, Pais, I. P, Ribeiro, A. I, \& Ramalho, J. C. Biochemical and molecular characterization of the antioxidative system of Coffea sp. Under cold conditions in genotypes with contrasting tolerance. Journal of Plant Physiology (2010). , 167, 333-342.

[195] Kocsy, G, Szalai, G, Vágújfalvi, A, Stéhli, L, Orosz, G, \& Galiba, G. Genetic study of glutathione accumulation during cold hardening in wheat. Planta (2000). , 210, 295-301.

[196] Takác, T, Luxová, M, \& Gašparíková, O. Cold induced changes in antioxidant enzymes activity in roots and leaves of two maize cultivars. Biologia Bratislava (2003). , 58, 875-880.

[197] Chu, J, Yao, X, \& Zhang, Z. Responses of wheat seedlings to exogenous selenium supply under cold stress. Biological Trace Element Research (2010). , 136, 355-363.

[198] Liu, X, Wang, L, Liu, L, Guo, Y, \& Ren, H. Alleviating effect of exogenous nitric oxide in cucumber seedling against chilling stress. African Journal of Biotechnology (2011). , $10,4380-4386$.

[199] Yang, H, Wu, F, \& Cheng, J. Reduced chilling injury in cucumber by nitric oxide and the antioxidant response. Food Chemistry (2011). , 127, 1237-1242.

[200] Turan, Ö, \& Ekmekçi, Y. Activities of photosystem II and antioxidant enzymes in chickpea (Cicer arietinum L.) cultivars exposed to chilling temperatures. Acta Physiologiae Plantarum (2011). , 33, 67-78. 
